\title{
Phylogeny and taxonomy of the Ophiostoma piceae complex and the Dutch elm disease fungi
}

\author{
Thomas C. Harrington ${ }^{1}$ \\ Doug McNew \\ Joseph Steimel \\ Department of Plant Pathology, Iowa State University, \\ Ames Iowa, USA 50010 \\ Deborah Hofstra ${ }^{2}$ \\ Roberta Farrell \\ Department of Biology, Waikato University, Hamilton, \\ New Zealand
}

\begin{abstract}
The Ophiostoma piceae complex forms a monophyletic group of insect-dispersed pyrenomycetes with synnemata (Pesotum) and micronematous (Sporothrix) synanamorphs. Other species of Ophiostoma outside of the $O$. piceae complex that form synnemata lack the Sporothrix state. The nine recognized species within the $O$. piceae complex are delimited by synnema morphology, growth rate at $32 \mathrm{C}$, mating reactions and sequences of the internal transcribed spacer (ITS) region of the rDNA operon. Phylogenetic analysis of the ITS region suggests two major clades in the complex, one that causes bluestain in primarily coniferous hosts and the other on primarily hardwood hosts. In the coniferous group are $O$. $p i$ ceae, $O$. canum, $O$. floccosum and the recently described $O$. setosum (anamorph Pesotum cupulatum sp. nov.). In the hardwood group are O. querci, O. catonianum, and the Dutch elm disease fungi: $O . u l m i, O$. novo-ulmi and $O$. himal-ulmi. Restriction fragment length polymorphisms of the ITS region are shown to be a convenient diagnostic tool for delimiting these species.
\end{abstract}

Key Words: Bluestain, Dutch elm disease, Graphium, Leptographium, Pesotum, Phialographium, Sporothrix

\section{INTRODUCTION}

Adaptations for insect dispersal (ascomata and conidiomata with sticky spore drops) have arisen frequently in the evolution of the ascomycetes (Black-

Accepted for publication September 29, 2000.

${ }^{1}$ Email: tcharrin@iastate.edu

${ }^{2}$ Current address: National Institute of Water and Atmospheric Research, PO Box 11-115, Hillcrest, Hamilton New Zealand. well 1994), and convergence on similar morphologies has greatly confused generic and species delimitations of both teleomorphs and anamorphs (Spatafora and Blackwell 1994). One of the largest groups of insect dispersed pyrenomycetes is the genus Ophiostoma, which is now recognized as distinct from Ceratocystis based on anamorphs and biology (Hoog and Scheffer 1984, Harrington 1981, 1987). Considerable confusion remains with generic limits for anamorphic fungi dispersed by insects, many of which form droplets of conidia at the apex of compact conidiomata called synnemata (Okada et al 1998). Some synnema-forming species have affinities to Ophiostoma H. \& P. Sydow, especially to the common sapwood-colonizing species $O$. piceae (Münch) H. \& P. Sydow and the Dutch elm disease fungus $O$. ulmi (Buisman) Nannf. (Okada et al 1998).

Synnematous anamorphs of Ophiostoma species have been placed in the genus Graphium Corda, though it is now thought that Graphium species are anamorphs of the Microascales (Okada et al 1998), and the genus name Pesotum Crane \& Schoknecht is available for the anamorphs of Ophiostoma species. Pesotum was based on the anamorph of O. ulmi and was characterized by the synanematous anamorph as well as a Sporothrix Hektoen \& Perkins ex Nicot \& Mariat synanamorph (Crane and Schoknecht 1973). Sporothrix conidiophores are micronematous, with conidiogenous cells that have prominent denticles at the point of conidium detachment (Hoog 1974, 1993). Secondary conidia are frequently formed from the primary Sporothrix conidia, and the name Hyalodendron Diddens has been used for such anamorphs. However, the name Hyalodendron should be reserved for basidiomycetous anamorphs, and there appears to be little need for distinguishing Sporothrix species with secondary conidium production (Hoog 1993). Species of Hyalorhinocladiella Upadhyay \& Kendrick form micronematous conidiophores similar to those of Sporothrix but without prominent denticles (Hoog 1993), and the conidiogenous cells of $\mathrm{Hy}$ alorhinocladiella resemble those of Pesotum species. Synnema forming anamorphs with phialidic conidium production were placed in Phialographium Upadhyay \& Kendrick, but Hoog and Scheffer (1984) and Wingfield et al (1991) do not distinguish Phialographium from Graphium (Pesotum sensu Okada et 
al 1998). Pesotum-type conidiophores with a single row of cells for the stipe (mononematous conidiophores) and a series of metulae at the stipe apex are placed in Leptographium Lagerb. \& Melin (Harrington 1988).

Okada et al (1998) used Pesotum for all synnema forming species with affinities to Ophiostoma, even those species with no Sporothrix synanamorph. This paper focuses on those Ophiostoma species with $P \ell^{-}$ sotum anamorphs sensu Crane and Schoknecht (1973), i.e., those that also have Sporothrix synanamorphs, such as $O$. piceae. Ophiostoma piceae was originally described by Münch (1907) from sapstain in pine and spruce but is now known as a complex of closely related Ophiostoma species with pigmented, synnematous anamorphs. Included in the complex are O. querci (Brasier and Kirk 1993) and the Dutch elm disease fungi, O. ulmi, O. novo-ulmi and O. himal-ulmi (Brasier and Mehrotra 1995). We found four other species closely tied to the $O$. piceae complex. We used DNA sequences of the internal transcribed spacer (ITS) region of the nuclear rDNA and mating studies to identify lineages and potential intersterility groups, and morphological and physiological comparisons were used to delimit species in the complex.

\section{MATERIALS AND METHODS}

Isolates.-The isolates most intensively studied and considered as part of the $O$. piceae complex are listed in TABLE I. Isolates are maintained in the collection at Iowa State University. For morphological comparisons, isolates were grown at room temperature (21-24 C) and lighting for 10-14 d on malt extract agar (MEA, 1.5\% Difco malt extract and $2.0 \%$ agar) or pine twig medium (MEA with a section of debarked Pinus strobus twig added to the molten agar medium, Harrington 1992). Isolates grown for DNA extraction were cultured on MYE broth (2\% malt extract, $1 \%$ yeast extract).

Temperature growth assay.-Isolates were grown at $32 \mathrm{C}$ on MEA because growth at this temperature was shown to distinguish $O$. piceae from O. querci (Brasier and Stephens 1993). Plates were inoculated using a plug of agar and mycelium (\#1 cork borer, from the advancing margin of a colony) placed upside down in the middle of the plate. The plates were incubated upside down in the dark. After $7 \mathrm{~d}$, the plates were removed from the incubator and two radial measurements taken for each plate. The assay was repeated twice at separate times, and the mean extent of radial growth determined from the three separate experiments.

Pairings.-Tests for sexual compatibility were conducted on MEA with pine twigs. Two methods of pairing were used. In most cases, a single isolate was grown on the agar medium for 1 wk and then spermatized with a conidial/mycelium slurry (Brasier and Kirk 1993, Harrington and McNew 1997). In other cases, two isolates were co-inoculat- ed with colonized agar plugs placed ca $5 \mathrm{~mm}$ apart. Single ascospore strains were obtained from an ascospore mass at the tip of a perithecium by suspending the mass in a light oil and streaking onto MEA plates (Harrington and McNew 1997).

PCR, DNA sequencing, and RFLP analysis.-The primers ITS1-F (5'-CTTGGTCATTTAGAGGAAGTAA-3') and ITS4 (5'-TCCTCCGCTTATTGATATGC-3') (Gardes and Bruns 1993, White et al 1990) were used to amplify the ITS region. Either extracted DNA (DeScenzo and Harrington 1994) at 10-100 ng per reaction or scraped mycelium with spores (Harrington and Wingfield 1995) were used as template for the polymerase chain reaction (PCR). The reaction mixture (100 $\mu \mathrm{L}$ final volume) contained 2.5 units Taq DNA polymerase (Promega Inc., Madison, Wisconsin), 1X PCR reaction buffer, $1.5 \mathrm{mM} \mathrm{MgCl} 2,200 \mu \mathrm{M}$ DNTPs, $5 \%$ (V/V) DMSO, and 0.25 or $0.50 \mu \mathrm{M}$ of each primer. Reaction mixtures were placed into a precooled $(4 \mathrm{C}$ ) thermocycler $(\mathrm{MJ}$ Research, Inc., Watertown, Massachusetts). Cycling conditions were an initial denaturation at $95 \mathrm{C}$ for $95 \mathrm{~s}$, followed by 35 cycles of $52 \mathrm{C}$ for $40 \mathrm{~s}$ (annealing), $72 \mathrm{C}$ for $2 \mathrm{~min}$ (extension), and $95 \mathrm{C}$ for $35 \mathrm{~s}$ (denaturation). There was a final extension step of $10 \mathrm{~min}$ at $72 \mathrm{C}$.

Amplicons were either sequenced using the primers ITS1-F and ITS4 or were digested with restriction enzymes following the manufacturer's recommendations. Sequencing was performed on a ABI PRISM 377 Genetic Analyzer (Perkin-Elmer Inc., USA) at the DNA Synthesis and Sequencing Facility (Iowa State University, Ames, Iowa) after purification using QIAquick PCR purification Kits (Qiagen Inc., USA) or Microcon-100 Microconcentrators (Amicon, Inc., USA).

The ITS sequences of 58 isolates of taxa in the $O$. piceae complex and an outgroup taxon (isolate C327 of Ophiostoma ips from New York, USA) were aligned manually and analyzed using PAUP 4.0 (Swofford 1998). A total of 616 unordered characters, including gaps, were utilized, with gaps considered a "fifth base" and all characters with equal weight. Sixty-four of the characters were parsimony-informative, and 491 characters were constant. Heuristic searches used stepwise (simple) addition and tree-bisection-reconnection. Bootstrap support (Felsenstein 1985) was determined from 1000 replications.

Polymorphisms in restriction sites of the ITS region were identified among species in the $O$. piceae complex using the online tool Webcutter 2.0 (http://www.ccsi.com/firstmarket/ cutter/cut2.html; Max Heiman, copyright 1997). The restriction enzyme HaeII (Gibco BRL, Inc., USA) produced the greatest number of polymorphisms among species; however, some species showed similar RFLP patterns with this enzyme. The restriction enzyme DdeI (Gibco BRL, Inc., USA) was used to differentiate some taxa. For either enzyme, the unpurified PCR product $(17.5 \mu \mathrm{L})$ was combined with $2.0 \mu \mathrm{L}$ of $10 \mathrm{X}$ buffer (supplied with the enzyme) and $0.5 \mu \mathrm{L}$ of restriction enzyme ( 5 units). Digestion was allowed to proceed for 1-16 $h$ at the appropriate incubation temperature for the enzyme employed. Restriction fragments and a 100-bp ladder (Gibco BRL, Inc., USA) were separated by electrophoresis for $3 \mathrm{~h}$ at 75 volts in $2 \%$ agarose gels (Bio-Rad, Inc., USA) with a TBE 
[89 mM Tris, $89 \mathrm{mM}$ boric acid, $2 \mathrm{mM}$ EDTA (pH 8.0)] buffer system. Gels were stained with ethidium bromide and illuminated with ultraviolet light. Molecular weights of the DNA fragments were determined using digital images and GelReader 2.0.5 (National Center for Supercomputing Applications, University of Illinois, Urbana-Champaign).

\section{RESULTS}

A wide range of synnema morphologies was seen among the isolates studied. All isolates forming both synnema and Sporothrix states were tolerant of cycloheximide (Harrington 1981) and had similar ITS sequences. The ITS sequence analysis grouped these isolates with bona fide isolates of $O$. piceae and $O$. querci (FIG. 1). Nine species in the $O$. piceae complex are recognized based on the ITS sequences (FIG. 1), mating reactions (TABLE I), cultural characteristics, and morphology (FIGS. 2-36, TABLE II). Other synnema-forming species, including Ophiostoma species excluded from the $O$. piceae complex (TABLE III) and isolates of $G$. penicillioides, the type species for $\mathrm{Gra}$ phium, did not form a Sporothrix synanamorph (Figs. 37-48). Their ITS sequences, where available, aligned poorly with sequences of $O$. piceae and $O$. querci.

Culture characteristics.-The distinguishing features of the species recognized in the $O$. piceae complex are listed in TABLE II. Morphological features are determined on MEA or MEA with pine twig medium, and a relatively weak medium is needed to discern these characteristics. Aroma is useful for distinguishing $O$. querci and $O$. setosum from the other species, and this feature is also best determined on MEA. Growth at $32 \mathrm{C}$ is a distinguishing feature for species in the complex (TABLE I), but accurate temperature control is needed. Protoperithecia, which are distinctly light-brown in $O$. querci, are most reliably produced $1 \mathrm{wk}$ after a conidial mass from a synnema is streaked over MEA or MEA with pine twig medium. The concentric rings of aerial mycelium that are diagnostic for the Dutch elm disease fungi (Brasier and Mehrotra 1995), O. querci, and O. setosum are also best seen on MEA.

Phylogenetic analyses.-Most of the sequences of the ITS region of other Ophiostoma species [e.g., O. pluriannulatum (Hedgcock) H. \& P. Sydow, O. stenoceras (Robak) Melin \& Nannf., and O. europhioides (Wright \& Cain) Solheim] could not be unambiguously aligned with the ITS sequences of the $O$. piceae complex, so only members of the $O$. piceae complex were included in analyses. Of the species outside of the $O$. piceae complex, the ITS sequence of $O$. ips (Rum- bold) Nannf. (AF198244) was reasonably similar, and $O$. ips was used as an outgroup taxon.

Two major clades in the $O$. piceae complex were inferred from parsimony analysis of the ITS sequences (FIG. 1). Ophiostoma piceae s.s., O. canum, O. floccosum and $O$. setosum formed a moderately supported group of species that are primarily found on conifer (Pinaceae) wood. Ophiostoma querci, O. catonianum, O. himal-ulmi, O. ulmi and O. novo-ulmi were found in a strongly supported branch of primarily hardwood (angiosperm) inhabiting fungi. The inferred hardwood-inhabiting clade was also seen in neighborjoining analysis (Swofford 1998), as was the branch containing $O$. himal-ulmi and $O$. querci, but the conifer-inhabiting species did not resolve as a single clade.

In most cases, the well supported branches in the phylogenetic analysis (FIG. 1) were of isolates with unique cultural or morphological characteristics (TABLE II). The ITS sequences of $O$. piceae and $O$. canum were identical, though all of the examined $O$. piceae isolates had cylindrical to obovoid conidia, and the two examined isolates of $O$. canum had globose conidia at the tip of synnemata (FIG. 13). The synnema stipes of $O$. piceae isolates were consistently black, while some synnemata of $O$. canum had brown stipes. Ophiostoma floccosum formed red-brown synnemata, frequently with lateral knobs (FIG. 16). Another branch in the ITS tree contained isolates of the recently describe $O$. setosum (Uzunovic et al 2000), which is characterized by darkly pigmented synnemata with the vertical cells of the stipe extending into the conidial mass, forming a cup-shaped structure (FIGS. 21-23).

As expected, the Dutch elm disease fungi O. ulmi and $O$. novo-ulmi were grouped as closely-related sister species (FIG. 1). The O. himal-ulmi ITS sequence was closer to that of $O$. querci than to that of $O$. ulmi. The $O$. querci clade included the only available isolate of $O$. catonianum and anomalous isolates from New Zealand and Viet Nam. Ophiostoma fagi had an ITS sequence identical to $O$. querci and is considered a synonym.

PCR-RFLP diagnostics.-Based on the ITS sequences used in FIG. 1, we identified restriction enzymes that would differentiate among the species in the $O$. piceae complex, except that no attempt was made to differentiate among the three Dutch elm disease species. Most species could be differentiated based on HaelI digestions (TABLE IV, FIG. 49). The HaeII restriction pattern for $O$. ulmi, O. novo-ulmi and $O$. himal-ulmi is the same, but it is distinct from that of O. querci and the other species (TABLE IV, FIG. 50). Ophiostoma piceae and $O$. setosum have the same re- 


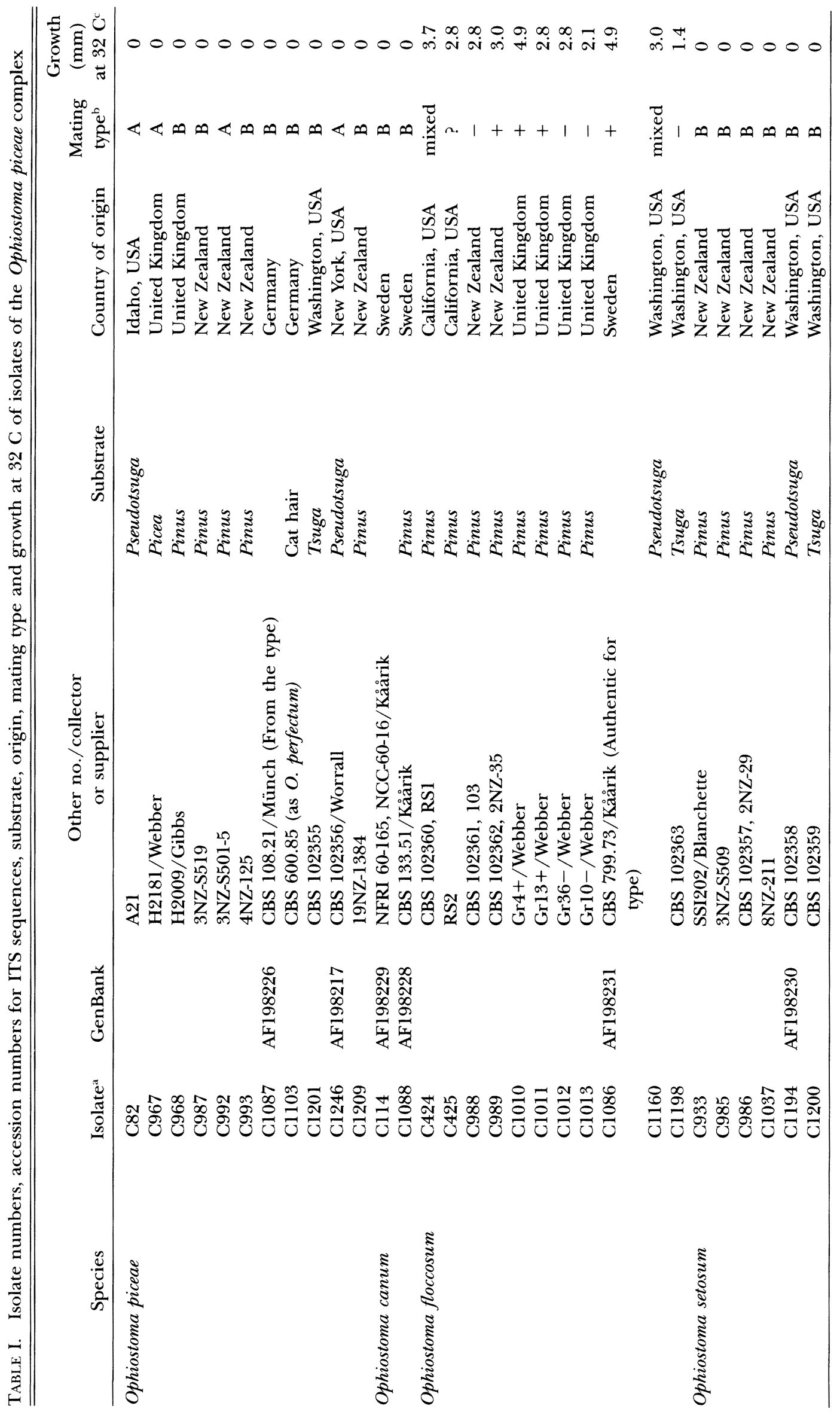




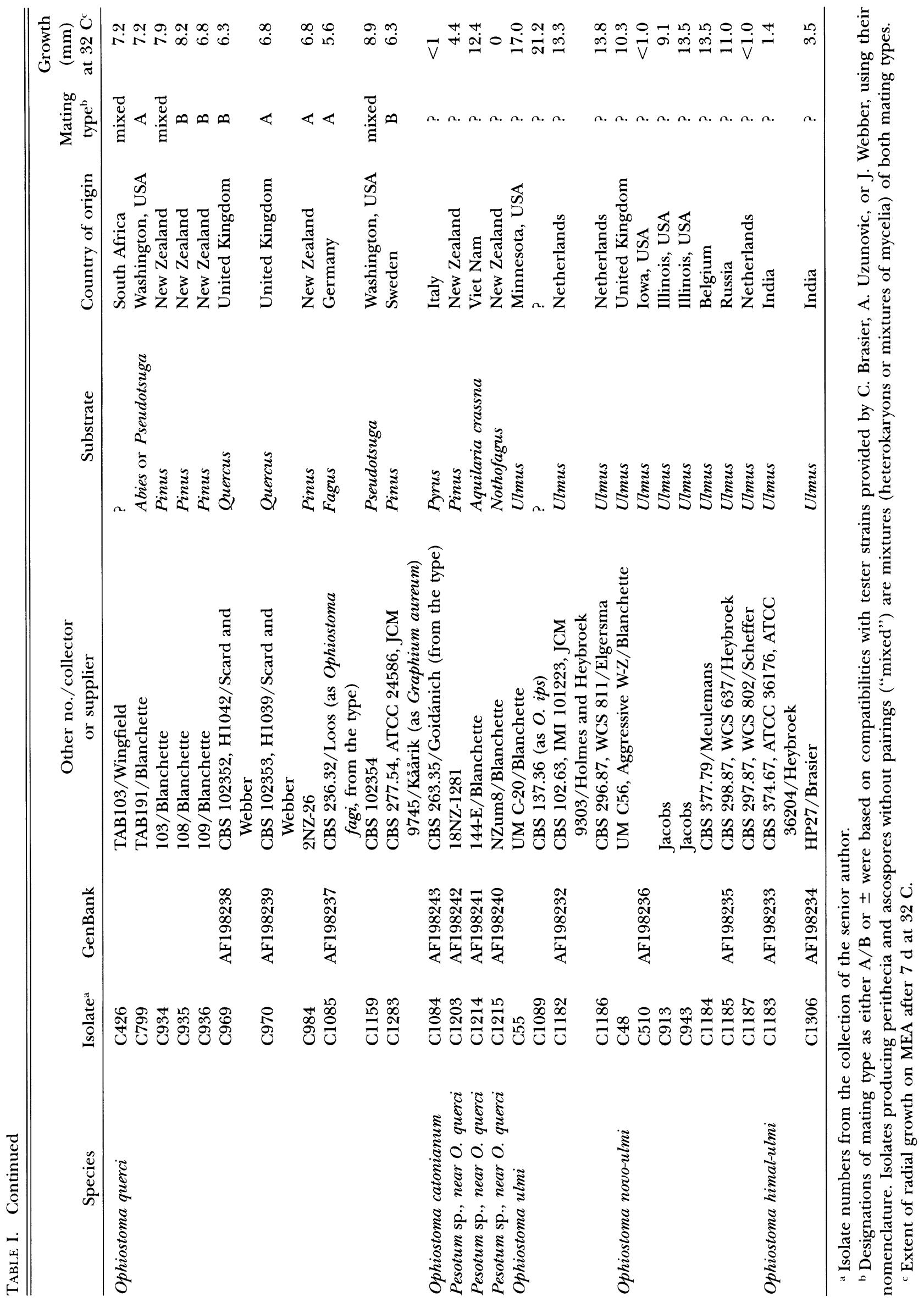




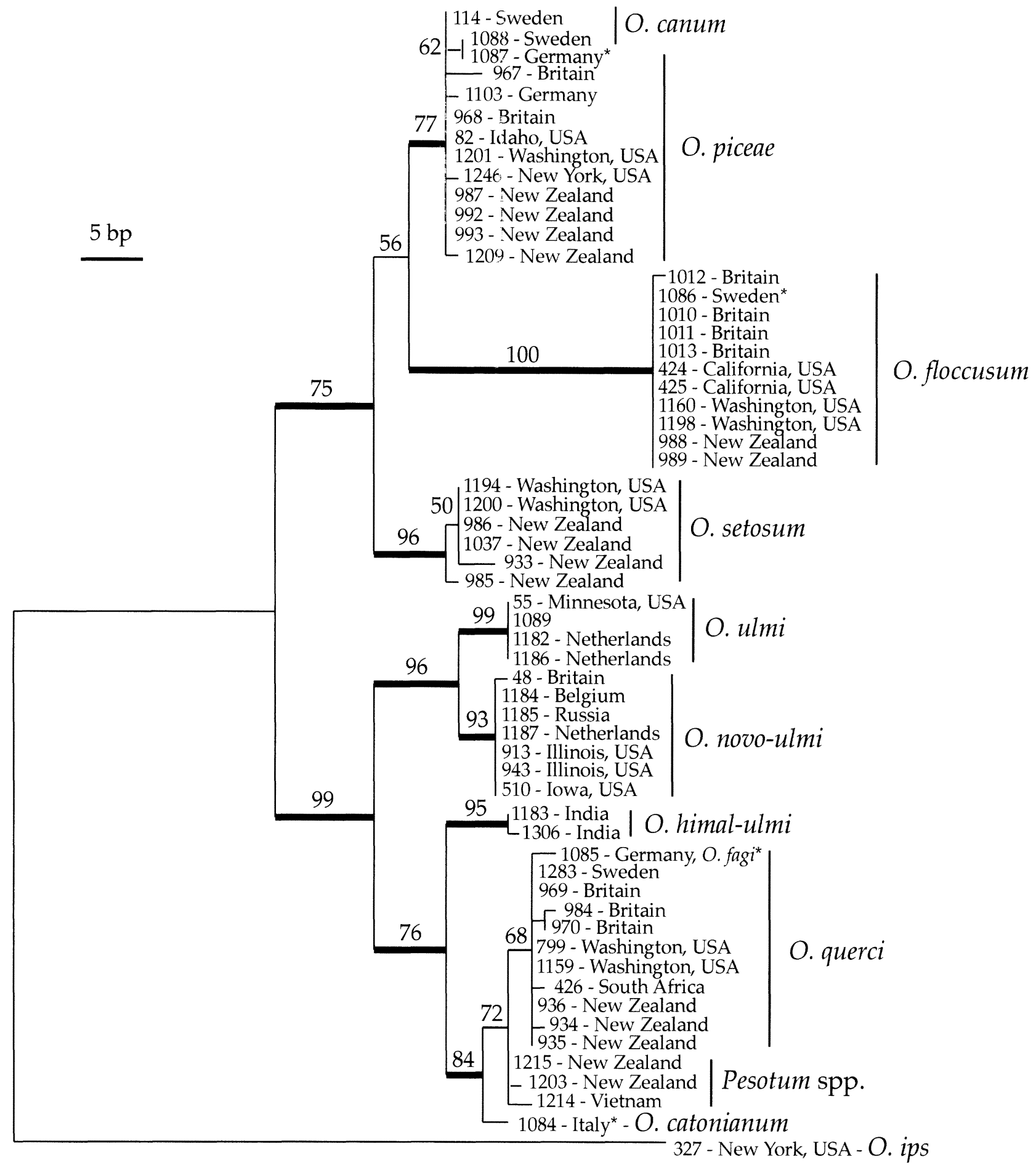

Fig. 1. One of four most parsimonious trees of the Ophiostoma piceae complex based on 616 characters, including gaps, of the ITS-1, 5.8S, and ITS-2 regions of the rDNA operon. The tree is rooted to Ophiostoma ips. Branches with strong support $(\geq 75 \%)$ are bolder, with bootstrap values $\geq 50 \%$ indicated above the branches. Total tree length $=181$ steps, consistency index $=0.8122$, retention index $=0.9663$. Asterisk indicates a culture from the holotype. 


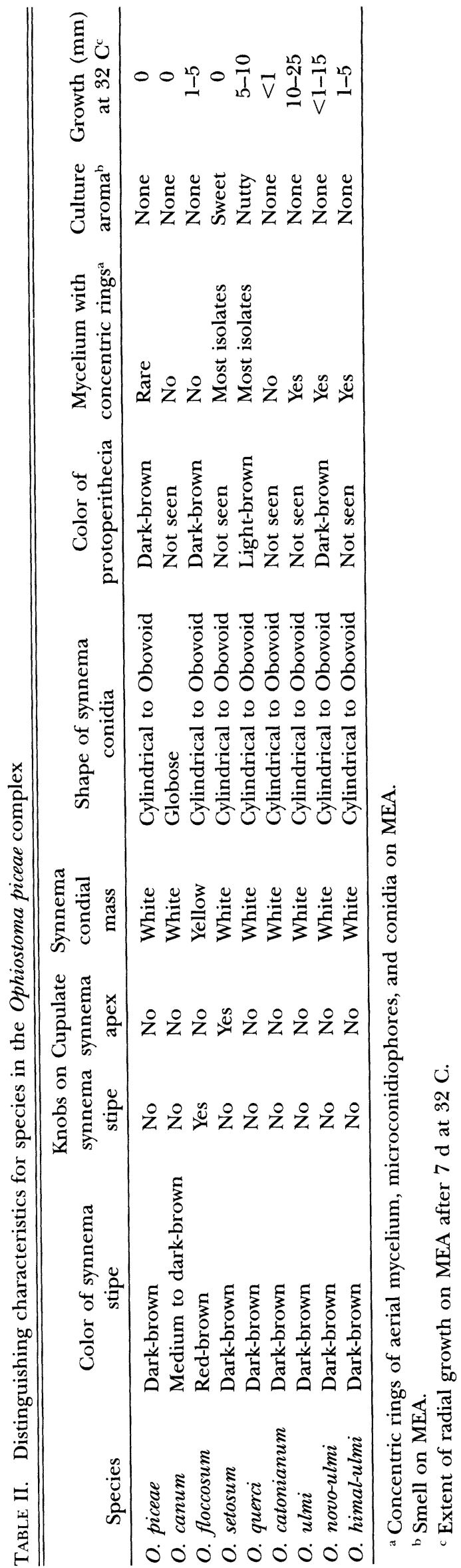

striction pattern with $\mathrm{HaeII}$, but these two species can be differentiated based on Ddel restriction fragments (TABLE IV, Fig. 49).

Mating reactions.-Tester isolates of each mating type of $O$. piceae, $O$. querci and an unidentified species found here to be $O$. floccosum were provided by $\mathrm{J}$. Webber, and A. Uzunovic provided tester strains of $O$. setosum. Isolates of the Dutch elm disease fungi were not tested, but most other isolates of the $O$. piceae complex were identified as either of the two mating types based on pairings with these and other selected tester strains (TABLE I). Most species formed perithecia and ascospores within two weeks of pairing, but $O$. floccosum isolates, when paired with isolates of opposite mating type, formed perithecia only after 4-6 wk, if at all. Isolates of $O$. piceae generally formed perithecia and ascospores when paired with isolates of opposite mating type. The two isolates of $O$. canum tested did not produce perithecia when paired with each other but produced a few perithecia with aborted asci and misshapen ascospores with mating type A strains of $O$. piceae (FIG. 14). No protoperithecia or perithecia were seen in our isolates of $O$. setosum (TABLE I) when paired among themselves or with other isolates of the $O$. piceae complex. However, these isolates were interfertile with a mating type A strain of $O$. setosum when incubated at $20 \mathrm{C}$ for 4-8 wk (Uzunovic et al 2000).

Ophiostoma querci isolates readily produced perithecia and ascospores when isolates of opposite mating type were paired. The isolate of $O$. fagi from the holotype also mated with $O$. querci testers. An isolate deposited in CBS as G. aureum (TABLE I) also paired with isolates of $O$. querci; however, we do not think this isolate represents $G$. aureum. An isolate from the holotype of $O$. catonianum, which is reportedly homothallic (Goidanich 1935), did not produce perithecia on its own and failed to mate with any other isolates.

\section{TAXONOMY}

Species of the Ophiostoma piceae complex.-Based on ITS sequence analysis, mating reactions, tests for growth at $32 \mathrm{C}$, and morphology, the following species are recognized in the complex.

Ophiostoma piceae (Münch) H. \& P. Sydow, Ann. Mycol. 17: 43. $1919 . \quad$ Figs. 2-12

$\equiv$ Ceratostomella piceae Münch, Naturw. Land. Forstw. 5: 547. 1907.

$\equiv$ Ceratocystis piceae (Münch) Bakshi, Trans. Br. Mycol. Soc. 33: 113. 1950. 

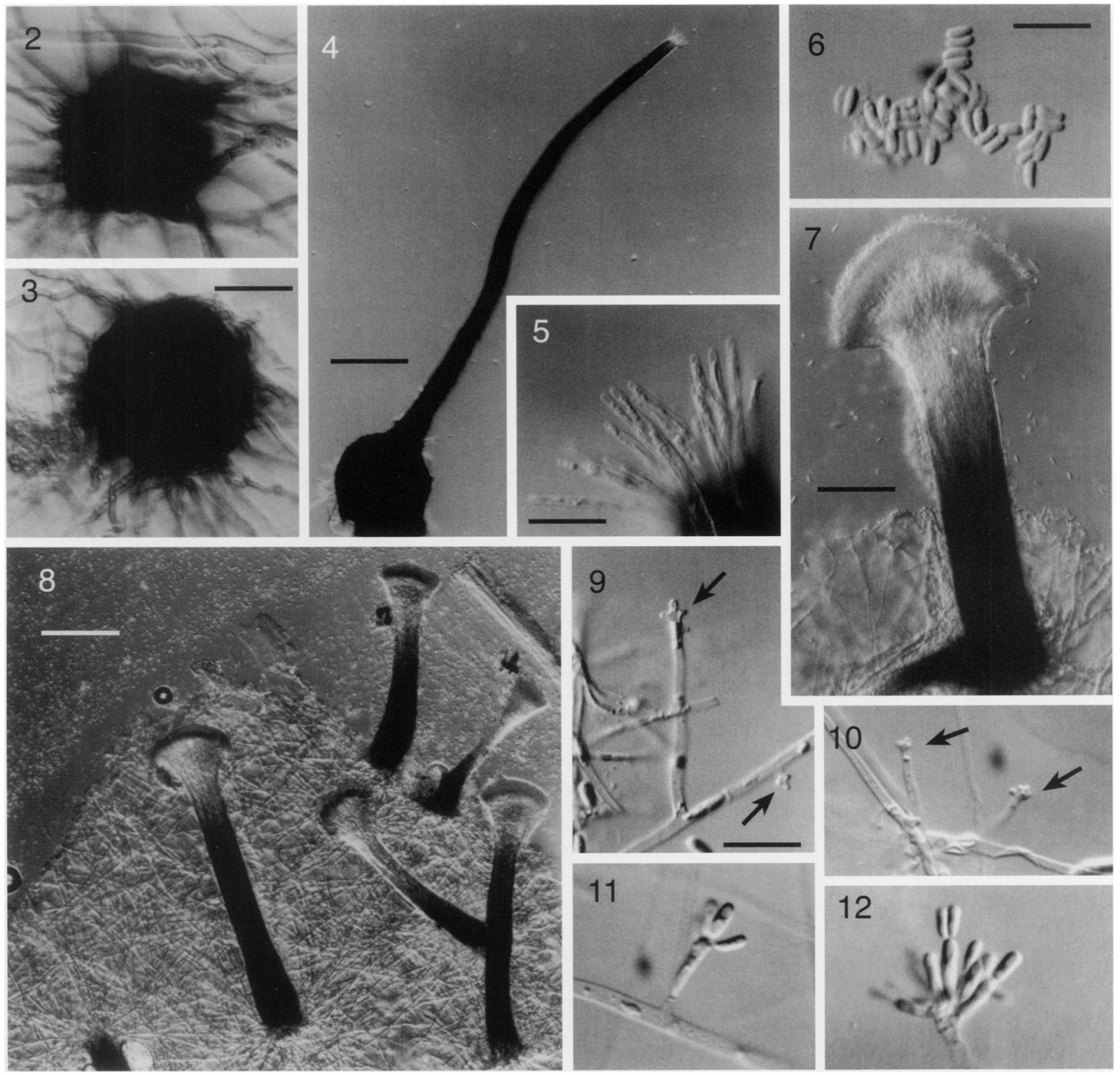

Figs. 2-12. Ophiostoma piceae. 2, 3. Protoperithecia. 4. Perithecium. 5. Ostiolar hyphae. 6. Ascospores. 7, 8. Synnemata. 9-12. Conidiophores and conidia of the Sporothrix synanamorph. Arrows in 9 and 10 indicate apex and side walls of conidiogenous cells, showing prominent denticles. 2, 3 from strain C967; 4-6 from a pairing of 967 and C1087; 7-12 from strain C1087, from the HOLOTYPE. Scale bars: $2,3=25 \mu \mathrm{m} ; 4,8=100 \mu \mathrm{m} ; 5,6,9-12=10 \mu \mathrm{m} ; 7=50 \mu \mathrm{m}$.

Anamorph. Pesotum piceae Crane \& Schoknecht, Am. J. Bot. 60: 348. 1973.

= Graphium piceae (Crane \& Schoknecht) Wingfield \& Kendrick, Mycol. Res. 95: 1331. 1991.

Commentary. Lectotype (BPI $595978=$ FP 14395) and other material (BPI 595979, BPI 595977) from Picea abies sapwood in Germany, collected by Münch, was deposited in BPI, apparently by Hedgcock. Although there is some mold growth on these specimens, the lectotype has, in addition to synnemata and perithecia, the Sporothrix synanamorph (with prominent denticles) typical of the $O$. piceae complex. The culture from the type (CBS 108.21= C1087) forms synnemata on wood and is of the $B$ mating type (TABLE I). This species is most commonly found on members of the Pinaceae throughout Europe, North America, and Japan (Brasier and Kirk 1993, Halmschlager et al 1994, Kim et al 1999, Morelet 1992, Pipe et al 1995). We have also identified isolates of $O$. piceae on the exotic Pinus radiata from New Zealand (TABLE I) and Chile.

Both the teleomorph and anamorphs of this spe- 
cies lack distinctive features, which has led to the proposal of numerous synonyms, all of which we have excluded from $O$. piceae. Synnemata stipe lengths of $O$. piceae and $O$. querci overlap, but those of $O$. piceae are larger (Hamschlager et al 1994). The size of the ascospores $(2.5-4.5 \times 1.5-2 \mu \mathrm{m})$ and range in size of synnematous conidia $(5-15 \times 1-3.5 \mu \mathrm{m})$ (Upadhyay 1981) of $O$. piceae overlap with the sizes of most other species in the complex. However, ITS sequences (FIG. 1, Kim et al 1999), mating reactions (TABLE I, Brasier and Kirk 1993), dark protoperithecia, the inability to grow at $32 \mathrm{C}$ (TABLE II, Brasier and Stephens 1993), and absence of a distinctive aroma or concentric rings on MEA (TABLE II) distinguish isolates of $O$. piceae from the more common and widespread $O$. querci. The synnemata of $O$. piceae are also similar to those of $O$. setosum, but the cup-like, conidial-bearing structure at the top of the synnemata of $O$. setosum distinguishes this species from the rest of the $O$. piceae complex. Red-brown synnemata distinguish $O$. floccosum from $O$. piceae and other members of this complex. Although $O$. canum has the same ITS sequence as $O$. piceae, the former is distinguished by its globose conidia and brown synnematous stipe.

Ophiostoma canum (Münch) H. \& P. Sydow, Ann. Mycol. 17: 43. 1919. FIG. 13

$\equiv$ Ceratostomella cana Münch, Naturw. Z. Forst. Landw. 5: 558.1907.

$\equiv$ Ceratocystis cana (Münch) Moreau, Rev. Mycol. (Paris) Suppl. Col. 17:22. 1952.

Anamorph. Pesotum canum (Upadhyay \& Kendrick) Okada \& Seifert, Can. J. Bot. 76: 1503. 1998.

$\equiv$ Pachnodium canum Upadhyay \& Kendrick, Mycologia, 67: 802. 1975 .

Commentary. The lectotype of $O$. canum (BPI595767 = BPI 2107) and two other specimens (BPI $595765=$ BPI 2110 and BPI $595766=$ FP 14394) from Münch were deposited in BPI by Hedgcock. The lectotype has perithecia and ascospores, while the other two specimens have synnemata and a Sporothrix anamorph but no perithecium. In addition to the isolates listed in TABLE I, we have examined Norwegian isolates NFRI 1652/2 (C1478) and NFRI 97-33/47 (C1477), both from Tomicus minor Hartig or stained Pinus sylvestris sapwood around galleries of this beetle, and globose conidia are also formed by these isolates. Mathiesen (1950, Mathiesen-Kåårik 1960) noted the association of $O$. canum with $T$. minor, and this beetle association distinguishes $O$. canum ecologically from $O$. piceae. MathiesenKåårik (1960) also noted physiological differences between $O$. canum and $O$. piceae. To date, $O$. canum is known only from pine in Europe, from Scandinavia and Germany.

Mathiesen (1950) and Upadhyay (1981) noted ascospores 5-6 6 1.5-2.5 $\mu \mathrm{m}$ and 4-6.5 $\times 1.5-3 \mu \mathrm{m}$, respectively, in $O$. canum, somewhat larger than those in $O$. piceae. The globose conidia of $O$. canum are particularly distinctive (FIG. 13) and separate it from all other members of the complex. Although we found that the ITS sequence of $O$. canum is the same as that of $O$. piceae, Kim et al (1999) reported that PCR primers specific for the ITS region of $O$. piceae were unable to amplify this fragment in $O$. canum. Hausner et al (1993) found that 259 of 261 aligned bases of the 26S rDNA gene were identical between a culture from the holotype of $O$. piceae and a Norwegian isolate of $O$. canum.

We have not been able to produce perithecia or ascospores with the two isolates (TABLE I) of $O$. canum that we have studied closely, perhaps because these two isolates are of the same mating type. However, we were able to produce a few perithecia when either of these two isolates were paired with mating type A testers of $O$. piceae. Ascospores produced from these hybrid crosses were generally inviable, but viable ascospore progeny were recovered from one perithecium of the cross between isolate C967 of $O$. piceae and isolate $\mathrm{C} 114$ of $O$. canum. Ten viable progeny were recovered, with globose conidia of $O$. can$u m$ and the elliptical conidia of $O$. piceae seen among the progeny. The fact that the $O$. canum isolates are only partially interfertile with $O$. piceae strains suggests that there is an intersterility barrier between these two species and further supports recognition of O. canum as distinct (Brasier 1993, Harrington and McNew 1998).

Ophiostoma floccosum Mathiesen, Svenka Bot. Tidskr. 45: 219. 1951. FIGS. 15-20

$\equiv$ Ceratocystis floccosa (Mathiesen) Hunt, Lloydia, 19: 36. 1956.

Anamorph. Pesotum aureum (Hedgcock) McNew et Harrington, comb. nov.

$\equiv$ Graphium aureum Hedgcock, Mo. Bot. Gard. Rept. 17: 94.1906.

Commentary. Although well described by Mathiesen (1951), this species has been rarely reported by others, probably because it was thought to be a morphological variant of $O$. piceae. Also, perithecia and ascospores are not commonly seen in cultures of $O$. floccosum, and perithecia often take many weeks to form in mating tests. We have examined specimens and cultures of this species from Europe, North America, Australia, and New Zealand (TABLE I), and also isolates from Korea. All of these isolates were from Pinaceae. 


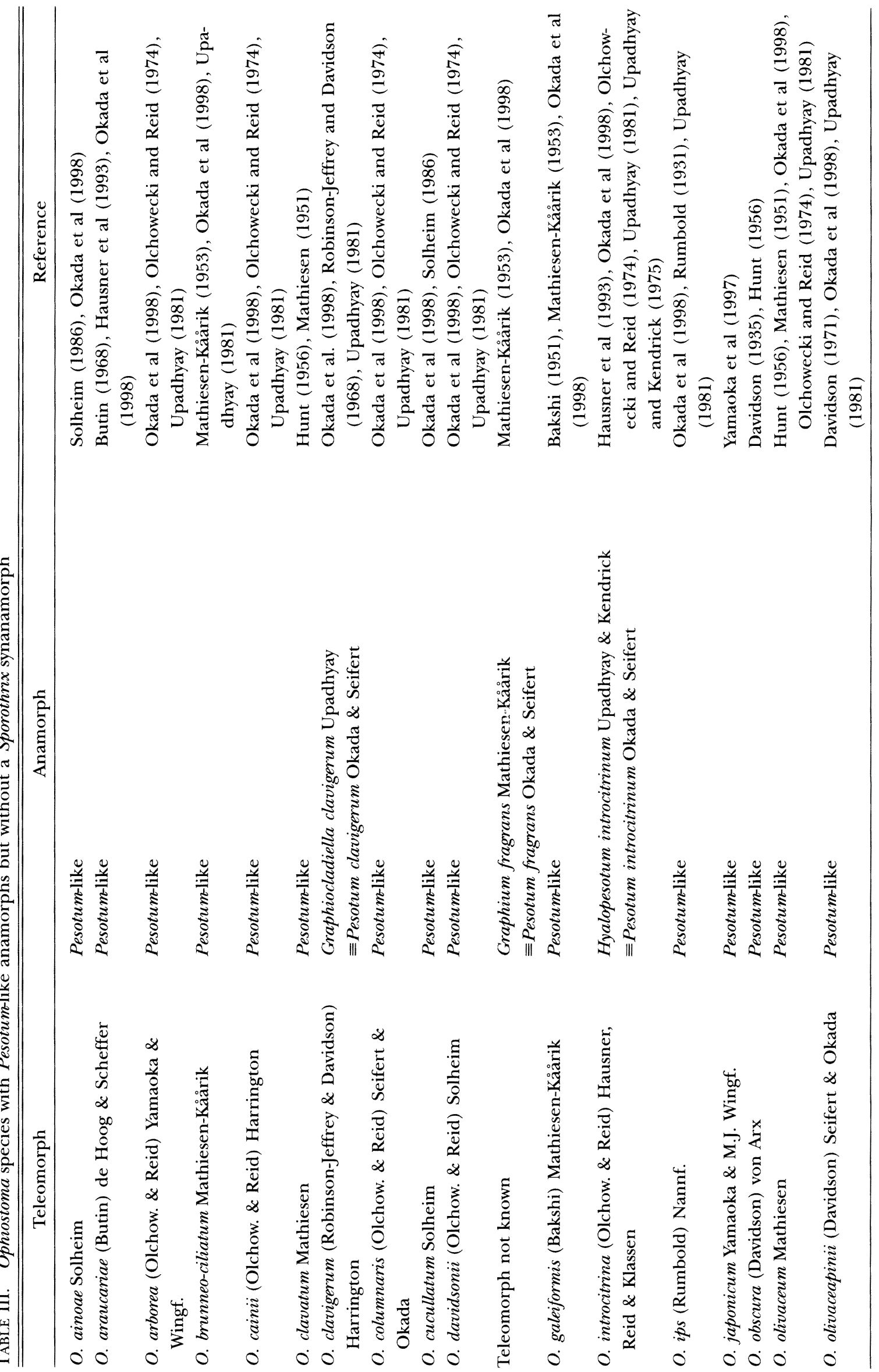


No holotype for $O$. floccosum was designated by Mathiesen, but herbarium material is apparently available in Statens Skogsforskningsinstitut Experimentalfältet, Sweden (Hunt 1956). A culture from Kåårik deposited in CBS (799.73) is considered authentic for the type but does not produce perithecia and ascospores, unless mated with - (minus) mating type strains. Tester strains of an intersterility group identified by J. Webber proved to be $O$. floccosum in morphology and ITS sequence. We deposited a dried specimen (BPI 746439) with perithecia and ascospores that resulted from pairing CBS 799.73 (from the holotype) and C1013 (a tester strain from Britain provided by Webber).

Mathiesen (1951) noted the relatively short ostiolar hyphae of this species when compared to $O$. piceae. We see little difference between the two species (FIGS. 5, 15), though ascospore masses at the top of perithecia are relatively small for $O$. floccosum. Synnemata of $O$. floccosum are distinctly red-brown, and lateral knobs on synnemata (FIG. 16) are common in all of the cultures of $O$. floccosum that we have examined. Also, secondary synnemata are frequently found emanating from the conidial mass on top of primary synnemata. Conidial masses on synnemata are yellow compared to white in fresh spore masses of other species in the complex.

Hedgcock (1906) described Graphium aureum from stained sapwood of Pinus strobus in Wisconsin. His description includes white to yellow conidial masses and stipes that are white at first, changing to yellow and often to dark brown at the base. The yellow conidial masses described by Hedgcock (1906) are typical for $O$. floccosum, though our cultures generally produce red-brown stipes instead of yellow to brown stipes. Hedgcock's type material is available (BPI 448701 and BPI 448702), and both specimens contain red-brown synnemata and black protoperithecia, which are also common for $O$. floccosum. A Sporothrix-like anamorph was noted by Hedgcock and was observed in the BPI specimens. Thus, we believe that Hedgcock's Graphium species is the anamorph of $O$. floccosum, and we have transferred his fungus to Pesotum. A culture deposited by Kåårik (CBS $277.54=$ ATCC $24586=\mathrm{JCM} 9745=\mathrm{C} 1283)$ as $G$. aureum mated with $O$. querci tester strains as discussed above and does not represent G. aureum.

Ophiostoma setosum Uzunovic, Seifert, Kim \& Breuil, Mycol. Res. 104:490. 2000.

Anamorph. Pesotum cupulatum McNew et Harrington sp. nov. FIGs. 21-26

Coloniae olivaceae-brunneae de infra, in agaro extracti malti diam. $55 \mathrm{~mm}$ attingens post 11 dies ad $25 \mathrm{C}$, odore 

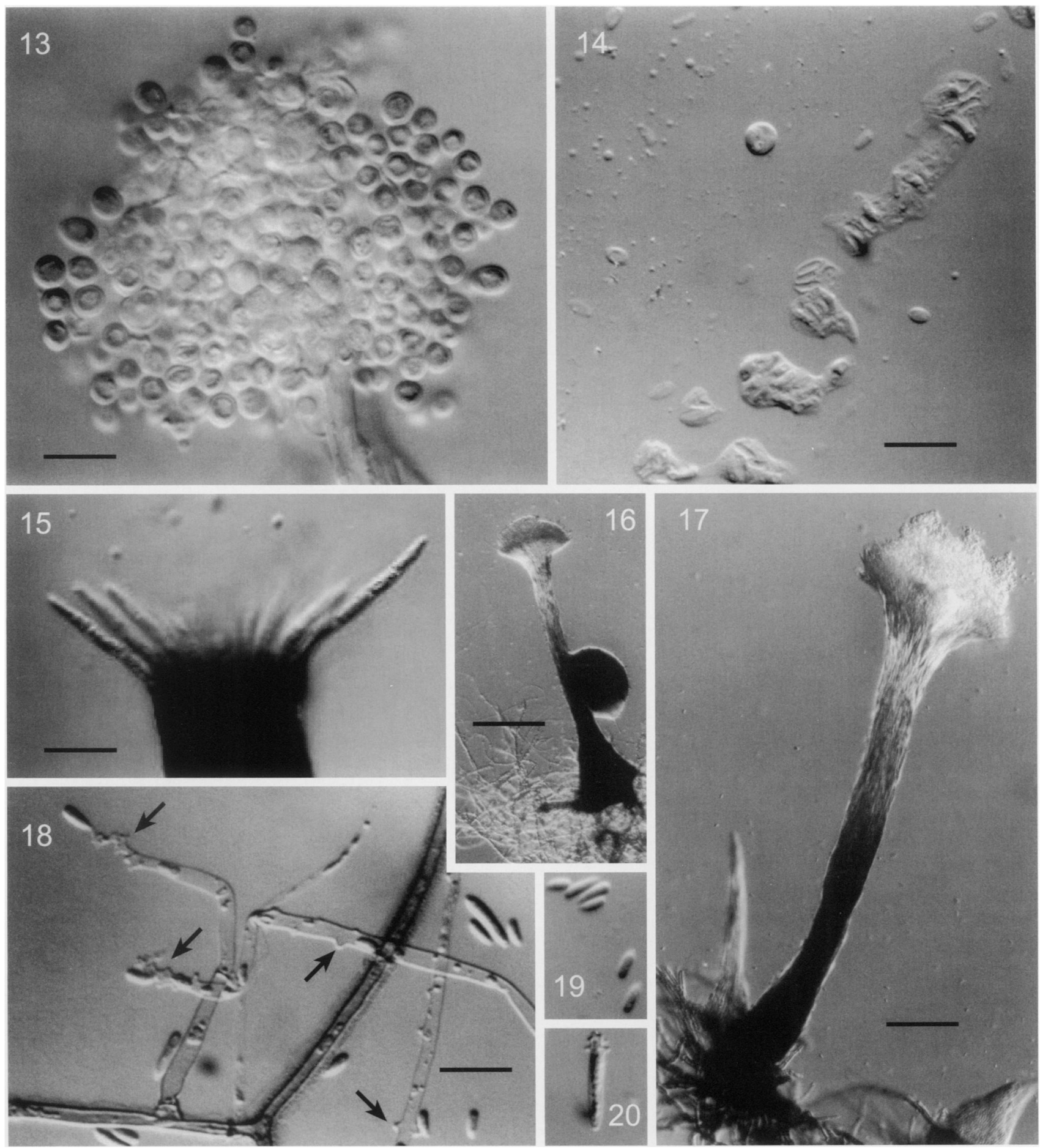

Figs. 13-20. Ophiostoma canum and $O$. floccosum. 13, 14. O. canum. 13. Synnema apex with globose conidia. 14. Aborted asci and ascospores from a crossing of $O$. canum and $O$. piceae. 13 from the LECTOTYPE (BPI 595765); 14 from a cross of strain C114 and strain C967. 15-20. O. floccosum. 15. Ostiolar hyphae. 16, 17. Synnemata. 18, 19. Conidiophores and conidia of Sporothrix synanamorph. Arrows in 18 indicate prominent denticles on apex and side walls of conidiogenous cells. 20. Primary conidium from Sporothrix synanamorph, with numerous denticles at apex where secondary conidia were attached. 15 from a cross of strain C1013 and C1086; 16-20 from strain 1086. Scale bars: $13-15=10 \mu \mathrm{m} ; 16=100 \mu \mathrm{m} ; 17=50 \mu \mathrm{m}$; $18-20=10 \mu \mathrm{m}$. 


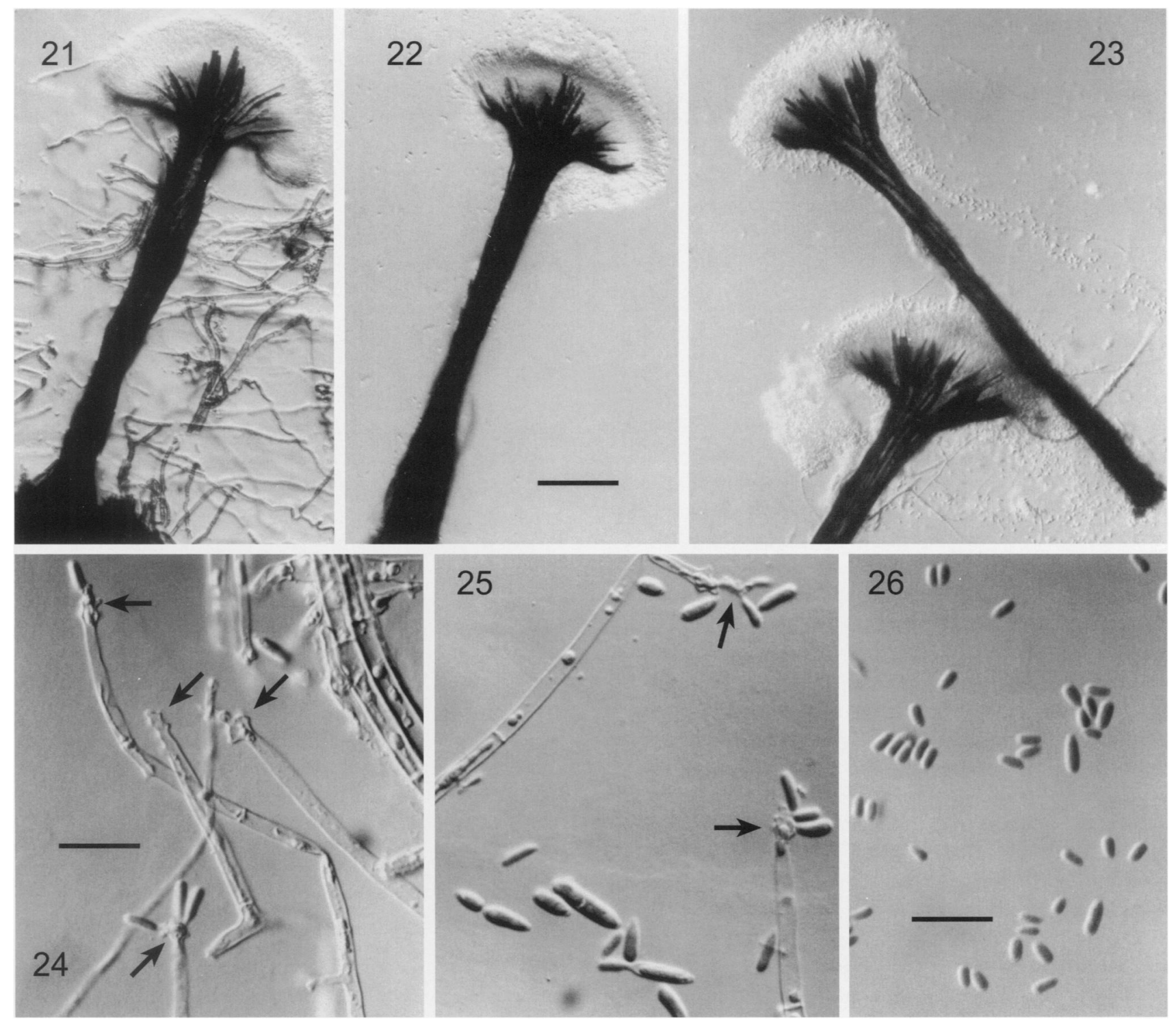

Figs. 21-26. Pesotum cupulatum, from the HOLOTYPE, anamorph of Ophiostoma setosum. 21-23. Synnemata. 24-25. Conidiophores and conidia of the Sporothrix synanamorph. Arrows in 24 and 25 indicate apex of conidiogenous cells, showing prominent denticles. 26. Conidia from synnema. Scale bars: 21-23 $=50 \mu \mathrm{m} ; 24-26=10 \mu \mathrm{m}$.

dulci. Incremento nullo ad 32 C. Synanamorpha primaria stipite $80-820 \mu \mathrm{m}$ longo, cum cellulis fuscae protrudens in zonam conidiogenam, calyx formans. Conidia unicellularia hyalina, cylindrica vel obovoidea, 3.0-5.5 $\mu \mathrm{m} \times 1.0-2.0 \mu \mathrm{m}$. Synanamorpha altera, simili Sporotrichi in denticules conspicui ubi sporae portatae et quoque in catena acropeta conidia holoblastica efferens.

Colonies on malt extract agar at $25 \mathrm{C}$ attaining a diameter of $55 \mathrm{~mm}$ in $11 \mathrm{~d}$, appearing olive-green to gray from above, olive-green to brown from below, with concentric rings developing on the upper surface of the mycelium with age, with a distinctly sweet aroma. Cultures not inhibited by cycloheximide. No growth at $32 \mathrm{C}$ on malt extract agar. Hyphae mostly submerged, aerial hyphae appressed, hyaline, smooth-walled, 1.0-3.0 $\mu \mathrm{m}$ wide, to brown, smooth or rough-walled, 2.5-4.0 $\mu \mathrm{m}$ wide. Conidiophores of two types: synnemata (FIGS. 21-23) single or in groups of two to three, simple or rarely branched, macronematous. Stipe dark brown to black at base, becoming lighter towards apex, 80-820 $\mu \mathrm{m}$ (mean $290 \mu \mathrm{m}$ ) long, base 10-40 $\mu \mathrm{m}$ (mean $23 \mu \mathrm{m}$ ) wide, tapering to $6-32 \mu \mathrm{m}$ (mean $16 \mu \mathrm{m}$ ) near the apex and flaring to $14-120 \mu \mathrm{m}$ (mean $45 \mu \mathrm{m}$ ). Many of the synnema stipe cells extend into the mass of conidiogenous cells and conidia, forming a cup of brown to black, setae-like structures. Conidiogenous cells proliferating sympodially with inconspicuous conidial scars. Synnematous conidia (FIG. 26) hyaline, one- 
TABLE IV. Restriction fragments of the amplified ITS product from species in the Ophiostoma piceae complex

\begin{tabular}{lll}
\hline \hline \multicolumn{1}{c}{ Species } & \multicolumn{1}{c}{$\begin{array}{c}\text { HaelI } \\
\text { fragments (bp) }\end{array}$} & $\begin{array}{c}\text { Ddel } \\
\text { fragments (bp) }\end{array}$ \\
\hline O. piceae/O. canum & $400,200,120$ & $290,270,190$ \\
O. floccosum & $280,200,(120)^{\mathrm{a}}$ & $290,270,190$ \\
O. setosum & $400,200,120$ & $270,(190)^{\mathrm{a}}, 100$ \\
O. querci/O. catonianum & 520,200 & $290,270,190$ \\
O. ulmi/O. novo-ulmi/ & 520,170 & $290,270,190$ \\
O. himal-ulmi & & \\
\hline
\end{tabular}

${ }^{a}$ Band sizes in parentheses are for two co-migrating bands.

celled, mostly guttulate, cylindrical to obovoid with rounded apices and slightly tapering bases, which may be truncate to rounded, 3.0-5.5 $\mu \mathrm{m}$ (mean 4.0 $\mu \mathrm{m}$ ) long and 1.0-2.0 $\mu \mathrm{m}$ (mean $1.6 \mu \mathrm{m}$ ) wide, accumulating in a white, gelatinous mass at the apex of the synnema. Micronematous conidiophores typical of the genus Sporothrix (Figs. 24, 25), arising terminally or laterally from hyphae, 11-156 $\mu \mathrm{m}$ (mean $73 \mu \mathrm{m}$ ) long, 1.0-4.0 $\mu \mathrm{m}$ wide at the base, tapering slightly at the apex, sometimes septate. Conidia produced at the apex of the conidiogenous cell (FIGS. 24, 25), which has prominent denticles, 0.5-1.5 $\mu \mathrm{m}$ long, where conidia have abscised along a rachis 1.5-21 $\mu \mathrm{m}$ (mean $5.5 \mu \mathrm{m}$ ) long. Conidiogenous cells may proliferate at or below the rachis. Sporothrix conidia hyaline, smooth-walled, 6.5-24 $\mu \mathrm{m}$ (mean $12.0 \mu \mathrm{m}$ ) long, 2.0-3.5 $\mu \mathrm{m}$ (mean $2.5 \mu \mathrm{m}$ ) wide, with a rounded apex and tapering base, often giving rise to secondary conidia at the apex and having denticles at the point of dehiscence of the secondary conidia. Secondary conidia hyaline, smooth-walled, guttulate, cylindrical to obovoid, 3.0-8.0 $\mu \mathrm{m}$ (mean $5.5 \mu \mathrm{m}$ ) long, 1.0-2.5 $\mu \mathrm{m}$ (mean $2.0 \mu \mathrm{m}$ ) wide, with a rounded apex and tapering at the base. No protoperithecium or perithecium seen.

HOLOTYPE. USA. WASHINGTON: Aberdeen, from stained wood of Pseudotsuga menziesii, Dec 1997, T. Harrington, BPI 746441, from isolate C1194 (CBS 102358).

Etymology. Refers to the cup-like structure at the top of the synnemata.

Commentary. Cultures representing the two mating types of a new Ophiostoma species $(O$. setosum) from Canada were kindly provided to us by A. Uzunovic (Uzunovic et al 2000) after our initial mating studies were completed. Pairings of our P. cupulatum isolates with the tester strains of $O$. setosum showed that all of our isolates were of the same mating type (B, TABLE I). After repeated pairings at $20 \mathrm{C}$, the isolates of $P$. cupulatum from the USA and New Zealand (TABLE I) were able to mate with the tester strains provided by Uzunovic. Morphologically, our isolates and the Canadian isolates (Uzunovic et al 2000) are identical.

Synnemata of $O$. setosum are similar in size and pigmentation to those of $O$. piceae and $O$. querci, but the apex of the synnemata of $O$. setosum is unique in its cup-like structure formed by extension of the external stipe cells into the conidial mass (FIGS. 21-23). The concentric rings of aerial mycelium found in most isolates and the distinctively sweet aroma of cultures of $O$. setosum also distinguish this species from O. piceae (TABLE II) . Ophiostoma setosum fails to grow at $32 \mathrm{C}$, as does $O$. piceae. In ITS sequence, $O$. setosum is close to $O$. piceae, and we have found $O$. setosum only on wood of conifers (Pinaceae), the most common substrate of $O$. piceae.

We originally isolated $O$. setosum from stained wood of Pinus radiata in New Zealand. Additional isolations were made from lumber of Psuedotsuga menziesii and Tsuga sp. from Washington, USA and from Pinus radiata wood from California. Uzunovic et al (2000) identified isolates from Picea, Pinus, and Tsuga in British Columbia, Canada and Oregon, USA. Thus, the species appears endemic to the $\mathrm{Pa}$ cific Coast of North America on various Pinaceae and was likely introduced to New Zealand. Synnemata of this species are commonly found in association with $O$. piceae, $O$. querci, and $O$. floccosum on bluestained wood.

Ophiostoma querci (Georgévitch) Nannf., in Melin and Nannf., Sven. Skogsvardsforen Tidskr. 32: 408. $1934 . \quad$ Figs. 27-36

$\equiv$ Ceratostomella querci Georgévitch, C. R. Acad. Sci. Paris 183: 759. 1926.

$\equiv$ Ceratocystis querci (Georgévitch) Moreau, Rev. Mycol. (Paris) Suppl. Col. 17: 22. 1952.

$=$ Ophiostoma fagi (Loos) Nannf., in Melin \& Nannf., Sven. Skogsvardsforen Tidskr. 32: 408. 1934.

$\equiv$ Ceratostomella fagi Loos, Arch. Mikrobiol. 3: 376. 1932.

$\equiv$ Ceratocystis fagi (Loos) Moreau, Rev. Mycol. (Paris) Suppl. Col. 17: 22. 1952.

$?=$ Ophiostoma roboris Georgescu \& Teodoru, Anal. Inst. Cerc. Exp. For., Ser. 1, 11: 207. 1948.

$\equiv$ Ceratocystis roboris (Georgescu \& Teodoru) Potlajchuk, Nov. Sist. Niz. Rast. 22: 154. 1985.

$?=$ Ophiostoma valachicum Georgescu \& Teodoru, Anal. Inst. Cerc. Exp. For., Ser. 1, 11: 198, 1948.

$\equiv$ Ceratocystis valachicum (Georgescu \& Teodoru) Potlajchuk, Novosti Sist. Niz. Rast. 22: 155. 1985.

$?=$ Ophiostoma kubanicum Sherbin-Parfenenko, Rak. Sos. Bol. List. Porod (Moscow) p. 49. 1953.

$\equiv$ Ceratocystis kubanicum (Sherbin-Parfenenko) Potlajchuk, Novosti Sist. Niz. Rast. 22: 153. 1985.

Anamorph. ?Graphium roboris Georgescu \& Teodoru, Anal. Inst. Cerc. Exp. For., Ser. 1, 11: 213. 1948. 

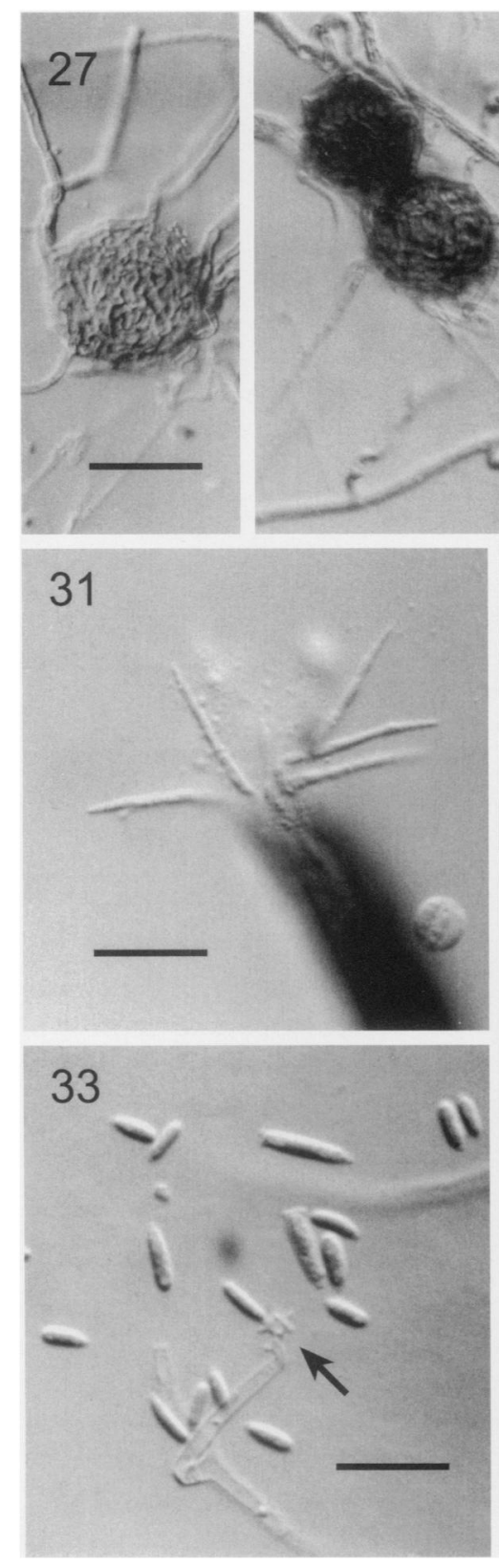

FIGS. 27-36. Ophiostoma querci. 27, 28. Protoperithecia. 29. Perithecium. 30. Perithecial neck with drops of ascospores (arrowheads). 31. Ostiolar hyphae. 32. Ascospores. 33, 34. Conidiophores and conidia of the Sporothrix synanamorph. Arrows in 33 and 34 indicate apex of conidiogenous cells, showing prominent denticles. 35. Synnema. 36. Conidia from synnema. 27, 28, 33-36 from strain C969; 29-32 from a pairing of 969 and C970. Scale bars: 27, $28=25 \mu \mathrm{m} ; 29=100 \mu \mathrm{m} ; 30=220$ $\mu \mathrm{m} ; 31-34,36=10 \mu \mathrm{m} ; 35=50 \mu \mathrm{m}$.

?= Graphium kubanicum Potlajchuk \& Schekunova, Novosti Sist. Niz. Rast. 22: 153. 1985.

Commentary. Unfortunately, no type material or culture was preserved by Georgévitch, and no Latin description was made. However, this name has been commonly applied to the so-called "hardwood" form of the $O$. piceae complex, and we continue to apply the name in this sense. Morelet (1992) designated neotype material (PFN 1463) for O. querci, which was derived from

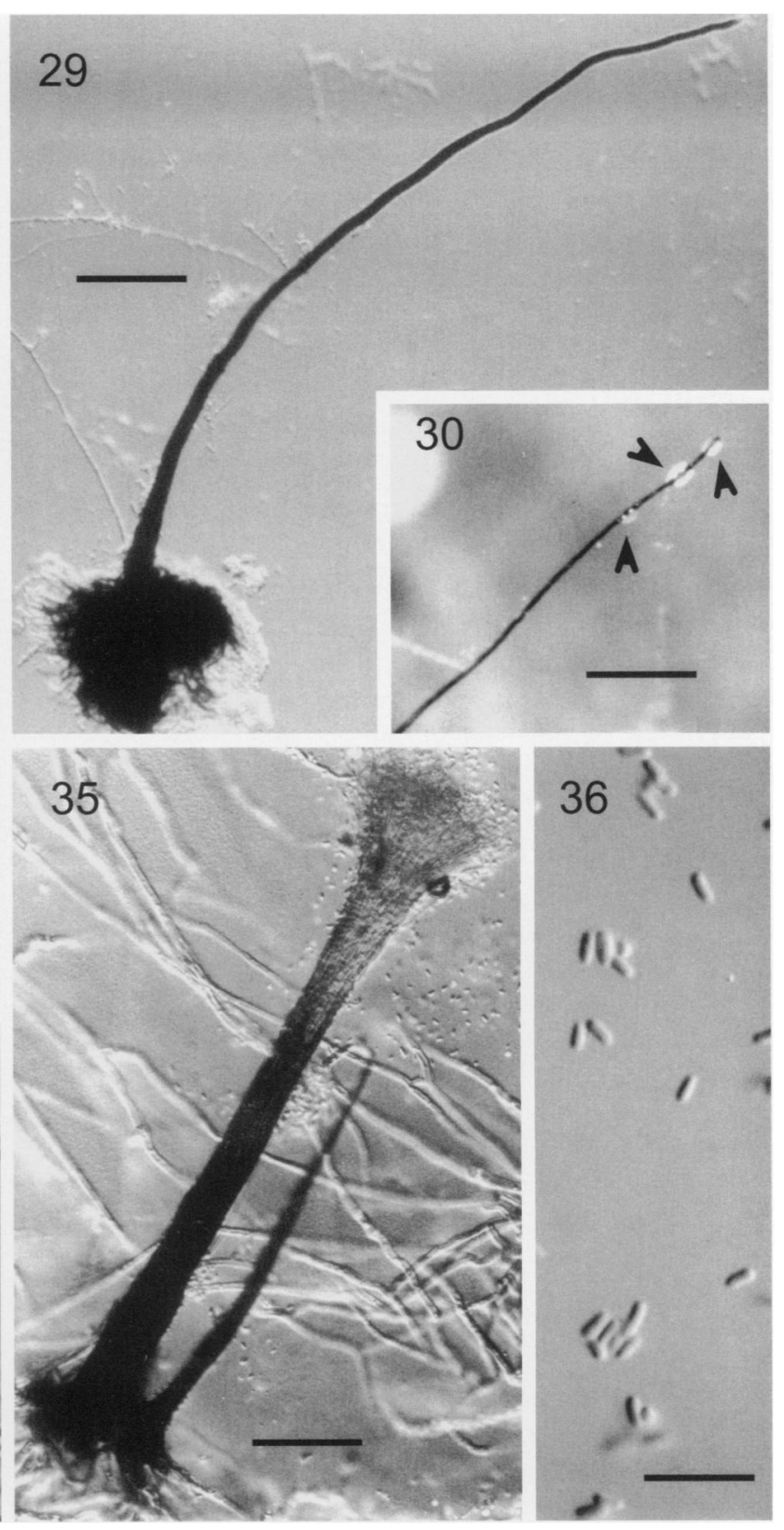


which are due to exudations of ascospores as the perithecial neck elongates. We have not seen this in perithecia of the other species in the O. piceae complex, but we have seen such ascospore droplets along the neck of $O$. pluriannulatum perithecia. Most isolates of $O$. querci and $O$. piceae form protoperithecia on MEA, but those of $O$. querci are a light, goldenbrown color (FIGs. 27, 28), while those of $O$. piceae are black (FIGS. 2, 3). Most isolates of $O$. querci have a nut-like aroma when growing on MEA, in contrast to an indistinct aroma in cultures of $O$. piceae (TABLE II). Also, O. querci isolates grow at $32 \mathrm{C}$, while $O$. piceae isolates do not (Brasier and Stephens 1993, TABLE I). Many isolates of $O$. querci form concentric rings of aerial mycelium on MEA, similar to isolates of the Dutch elm disease fungi (TABLE II).

In pairings, $O$. querci produces perithecia and ascospores when isolates of opposite mating types are paired. An isolate (CBS 236.32) of $O$. fagi from the holotype had the ITS sequence of $O$. querci and mated with this species. It is, therefore, considered a synonym of $O$. querci, as was suggested by Brasier (1993). Three other Ophiostoma species (O. roboris, O. kubanicum, and $O$. valachicum) from Quercus in eastern Europe are likely synonyms of $O$. querci (Przybyl and de Hoog 1989), but there appears to be no authentic material available of these three species (Przybyl and de Hoog 1989). From descriptions by Potlajczuk and Schekunova (1985), O. roboris, O. kubanicum, and $O$. valachicum are indistinguishable from $O$. querci. Both $O$. roboris and $O$. kubanicum have been isolated from Quercus from central Europe to Azerbaijan (Brasier and Kirk 1993). An isolate of $O$. roboris from Azerbaijan by Guseinov paired with testers of $O$. querci to produce perithecia and ascospores (TABLE I), as was reported by Brasier and Kirk (1993).

Both Morelet (1992) and Okada et al (1998) list Pesotum pirinum as the anamorph of $O$. querci. We consider $O$. catonianum and its anamorph, $P$. pirin$u m$, as distinct from $O$. querci and $O$. piceae, leaving no clear anamorph name for $O$. querci. An isolate deposited as Graphium aureum (CBS 277.54, C1283) had the ITS sequence of $O$. querci, and it paired with our tester strains of $O$. querci. However, examinations of the holotype specimen and description of $G$. aureum (Hedgcock 1906) show that it is the anamorph of $O$. floccosum, as noted above, and CBS 277.54 was misidentified as $G$. aureum. Should $O$. roboris prove to be a validly described synonym of $O$. querci, then the anamorph name Graphium roboris is available as a basionym for the anamorph of $O$. querci.

Ophiostoma querci appears to be a widespread species and is commonly found on conifers and hardwoods throughout Europe and North America (Brasier and Kirk 1993, Halmschlager et al 1994, Kim et al 1999, Morelet 1992, Pipe et al 1995). In addition to isolates from South Africa and New Zealand listed in TABLE I, we have identified isolates of $O$. querci from $P$. radiata in Australia, Eucalyptus sp. in Uruguay and Pinus sp. in Korea. In Europe, it apparently occurs more frequently on hardwoods, especially oak, than on conifers (Brasier and Kirk 1993, Halmschlager et al 1994, Morelet 1992, Pipe et al 1995). In North America and the Southern Hemisphere, however, sapwood of Pinaceae is a common substrate.

Ophiostoma catonianum (Goid.) Goid., Boll. Stn. Patol. Veg. Roma, N. S., 15: 125. 1935.

$\equiv$ Ceratostomella catonianum Goid., Atti. Accad. Naz. Linc. Rc. Ser. 6, 21: 199. 1935.

$\equiv$ Ceratocystis catonianum (Goid.) Moreau, Rev. Mycol. (Paris) Suppl. Col. 17: 22. 1952.

Anamorph. Pesotum pirinum (Goid.) Okada \& Seifert, Can. J. Bot. 76: 1504. 1998.

$\equiv$ Graphium pirinum Goid., Boll. Stn. Patol. Veg. Roma, N. S., 15: 132. 1935.

Synanamorph. Sporothrix pirinum (Goid.) Morelet, Extrait Annales S.S.N.A.T.V. 44: 110. 1992.

$\equiv$ Hyalodendron pirinum Goid., Boll. Stn. Patol. Veg. Roma, N. S., 15: 136. 1935.

Commentary. Although there appears to be no type specimen for O. catonianum (Hunt 1956), a culture of $O$. catonianum deposited by Goidanich is available from CBS (263.35). The ITS sequence of this isolate is unique but near that of $O$. querci (FIG. 1). The culture does not form protoperithecia, perithecia, or synnemata, and pairings with testers of the other species in the complex failed to result in perithecia. A Sporothrix anamorph was found in the culture, however. This culture grows very slowly at $32 \mathrm{C}$, in contrast to $O$. querci (TABLE I).

Goidanich (1935) described this species from $P y$ rus (pear) in Italy. His description of $O$. catonianum indicates that the perithecial necks are shorter and the ostiolar hyphae longer than those of $O$. piceae, $O$. querci, and $O$. floccosum. He also states that single ascospore and single conidial isolates produce perithecia and ascospores. Thus, $O$. catonianum is homothallic, in contrast to the heterothallic mating system of all other species in the complex.

Ophiostoma ulmi (Buisman) Nannf., in Melin and Nannfeldt, Svenska Skorgsfor. Tidskr. 32: 408. 1934.

$\equiv$ Ceratostomella ulmi Buisman, Tijdskr. Plantenziekt. 38: 1. 1932.

$\equiv$ Ceratocystis ulmi (Buisman) Moreau, Rev. Mycol. (Paris) Suppl. Col. 17: 22. 1952.

Anamorph. Pesotum ulmi (Schwarz) Crane \& Schoknecht, Am. J. Bot. 60: 348. 1973. 
$\equiv$ Graphium ulmi Schwarz, Meded. Phytopathol. Lab. 5: 13.1922.

Commentary. This species, and the following two species, are capable of causing Dutch elm disease, a vascular wilt disease, in inoculated elms (Brasier and Mehrotra 1995). Morphological and cultural characteristics of these three species are contrasted in detail by Brasier and Mehrotra (1995) and need not be reiterated here.

The natural geographic range of $O$. ulmi is still not clear (Brasier and Mehrotra 1995), but it was apparently introduced into Europe and North America, where dramatic losses to Ulmus species were found. In contrast to $O$. querci, synnemata are generally not formed by isolates of $O$. ulmi on MEA or MYEA, but addition of twigs or linoleic acid to the medium stimulates synnemata production (Dalpé and Montant 1980). The typically pronounced concentric rings of the mycelium and relatively fast growth at $32 \mathrm{C}$ distinguish this species from $O$. novo-ulmi (Brazier and Mehrotra 1995) and O. querci. Only O. ulmi isolates grow at a relatively rapid rate at $32 \mathrm{C}$ (TABLE I), and Brasier and Mehrotra (1995) have speculated that it may occur naturally in a tropical region of Asia.

Ophiostoma novo-ulmi Brasier, Mycopathologia 115: 155. 1991.

Commentary. The natural geographic range of $O$. novo-ulmi is also in question, though an Asian origin is suggested (Brasier and Mehrotra 1995). Like $O$. ulmi, $O$. novo-ulmi causes a devastating vascular wilt disease in Ulmus species in Europe and North America, and the fungus has been introduced to New Zealand. Isolates of $O$. novo-ulmi and $O$. ulmi are similar to each other, though differences in mycelium texture, temperature sensitivity, and growth rate (Brasier and Mehrotra 1995) separate these species, which are closely related based on ITS sequences (FIG. 1).

Ophiostoma himal-ulmi Brasier \& M. D. Mehrota, Mycol. Res. 99: 211. 1995.

Commentary. Thus far, O. himal-ulmi is known only from the Himalayas from branches of Ulmus species attacked by bark beetles (Brasier and Mehrotra 1995). Although thought to be closely related to $O$. $u l m i$ and $O$. novo-ulmi, the ITS sequence data suggest that it is more closely related to $O$. querci. Unlike the other Dutch-elm disease fungi, $O$. himal-ulmi produces synnmenata on MEA, and morphologically it is difficult to distinguish from $O$. querci. However, cultures of $O$. himal-ulmi do not produce the nutty aroma of $O$. querci and grow slower than $O$. querci isolates at 32 C (TABLE I).
Synnematous Ophiostoma species without Sporothrix synanamorphs.-A number of Ophiostoma species have been noted to have synnematous anamorphs but no Sporothrix synanamorph (TABLE III). Ophiostoma novae-zelandiae (Hutchison \& Reid) Rulamort was said to rarely form synnemata (Hutchison and Reid 1988a), but we have not seen synnema in a dried culture from the holotype [WIN (M) 869] or in living cultures (UAMH 9556-9) from New Zealand (Hutchison and Reid 1988a). The original description may have been from a culture of more than one species. Perithecia and ascospores as described by Hutchison and Reid (1988a) and as seen in the holotype look like those of $O$. pluriannulatum, which is not reported to have synnemata (Hunt 1956, Upadhyay 1981).

Reports of synnemata in Ophiostoma species other than those in the $O$. piceae complex have been of species without known Sporothrix synanamorphs, though many produce Hyalorhinocladiella synanamorphs. These species (TABLE III) are excluded from the $O$. piceae complex. Two such species are discussed below.

Pesotum fragrans (Mathiesen-Kåårik) Okada \& Seifert, Can. J. Bot. 76: 1503. $1998 . \quad$ Figs. 37-40

三 Graphium fragrans Mathiesen-Kåårik, Medd. Statens Skogsforskningsinst. Inst. 43: 59. 1953.

Commentary. An isolate deposited as Graphium fragrans $(\mathrm{C} 1224=$ CBS $279.54=$ ATCC 24590$)$ by Kåårik likely represents the species. However, this Swedish isolate no longer produces synnema but does produce Leptographium-like or Hyalorhinocladiella-like conidiophores (FIGs. 37-39) that may represent degenerate synnemata. No denticles typical of Sporothrix are seen in the culture. The conidia (FIG. 40) of this species are longer than those of members of the $O$. piceae complex.

This species does appear to be an anamorph of an Ophiostoma species based on ITS sequence (AF198248), but it does not fall into the O. piceae complex (data not shown). Similar cultures with almost identical ITS sequences were isolated from pine wood in California, New Zealand and Australia (unpubl).

Okada et al (1998) list CBS 219.83 as authentic for the type of $G$. fragrans, but this isolate was collected by Solheim, not Kåårik, and CBS 279.54 should be authentic for the type. Okada et al (1998) found sympodial proliferation of the conidiogenous cells of synnematous and mononematous conidiophores of CBS 219.83 , and they also found that the $18 \mathrm{~S}$ rDNA sequence of this isolate was similar to that of other Ophiostoma species. 

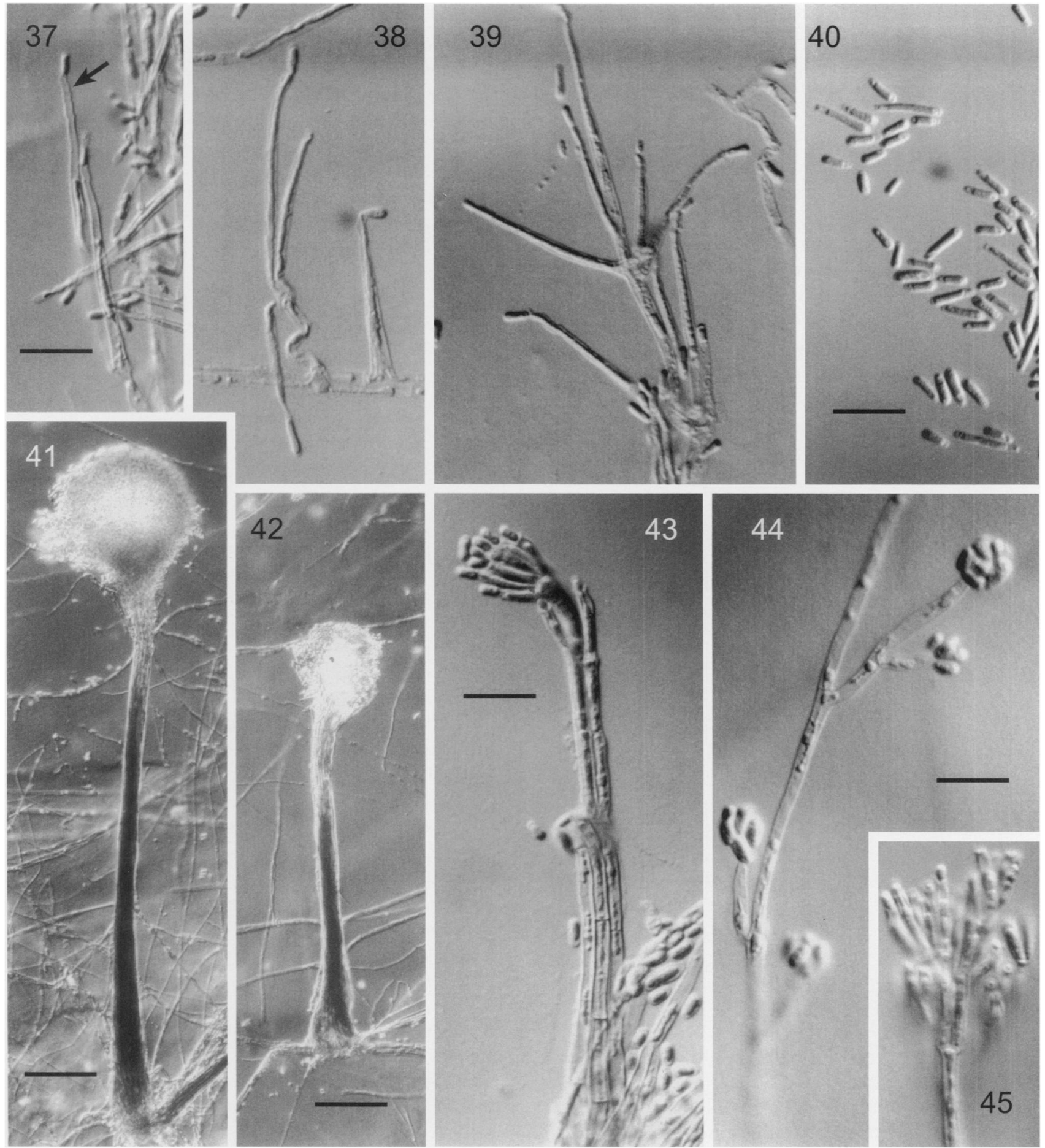

FiGs. 37-45. Graphium fragrans and O. cucullatum. 37-40. G. fragrans strain C1224, AUTHENTIC FOR TYPE. 37-39. Conidiophores and conidia. Arrow in 37 indicates abscission scars along the side of apex of conidiogenous cell. 40 . Conidia. 41-45. O. cucullatum. 41-42. Synnemata. 43. Synnema with metulae, phialides, and conidia. 44. Micronematous conidiophores and conidia. 45. Apex of Leptographium-type conidiophore with metulae, phialides and conidia. 41, 44 from strain 1216 as $O$. cucullatum; 42, 43, 45 from strain C1222, AUTHENTIC FOR TYPE of Phialographium erubescens. Scale bars: 37$40,43-45=10 \mu \mathrm{m} ; 41,42=50 \mu \mathrm{m}$. 
Ophiostoma cucullatum Solheim, Nord. J. Bot. 6: 202. 1986. FIGS. 41-44

Anamorph. Phialographium erubescens (Mathiesen-Kåårik) Harrington et McNew, comb. nov.

$\equiv$ Pesotum erubescens (Mathiesen-Kåårik) Okada, Studies in Mycology 45: 184. 2000.

$\equiv$ Graphium erubescens Mathiesen-Kåårik, Medd. Statens Skogsforskningsinst Inst. 43: 62. 1953.

Commentary. The ITS sequence of $O$. cucullatum (AF198246, from isolate C1216 = NFRI 81-83/2, collected by Solheim) differed in only a single base substitution from that of Graphium erubescens (CBS $278.54=$ JCM $9747=$ C1222, from the holotype) and another culture deposited by Kåårik as $G$. album (CBS 276.54 $=$ JCM $9744=$ C1225, ITS sequence $=$ AF198247). This isolate of G. album is morphologically identical to $G$. erubescens and is distinct from specimens representing G. album as emended by Hedgcock (1906). We believe that Kåårik's isolate of $G$. album was misidentified and that G. erubescens is the anamorph of $O$. cucullatum.

The ITS sequences of $O$. cucullatum and G. erubescens were not similar to those of other members of the $O$. piceae complex. Okada et al (1998) found the $18 \mathrm{~S}$ rDNA sequence of $O$. cucullatum to be similar to that of $O$. europhioides, which has a Leptographium anamorph. Likewise, Hausner et al (1993) found the partial 28S rDNA sequence of $O$. cucullatum to be similar to those of other Ophiostoma species with Phialographium and Leptographium anamorphs.

All three cultures of $O$. cucullatum (C1216, C1222, C1225) failed to form Sporothrix conidiophores on MEA but did form synnemata with loosely- to tightlyfused outer stipe cells (FIGS. 41-43), with gradations to mononematous (Leptographium-type) conidiophores (FIG. 45). In general, the aerial synnemata are more tightly woven, and the synnemata submerged in the agar medium are a loose collection of Leptographium-like conidiophores. The conidiogenous cells on top of the synnematous and mononematous conidiophores are phialidic based on light microscopy (FIGS. 43, 45), as described for the synnemata of O. cucullatum (Solheim 1986). Okada et al (2000) reported that the conidiogenous cells of $P$. erubescens (isolate CBS 278.54) usually proliferate percurrently but also have an intermediate mode between sympodial proliferation and phialidic ontogeny based on scanning electron microscopy.

The anamorph of $O$. sagmatosporae also has conidiogenous cells that are phialidic in light microscopy (Seifert and Okada 1993), and this anamorph was the basis for the synnema-forming genus Phialographium Upadhyay \& Kendrick. Okada et al (1998) consider the synnematous anamorphs of $O$. sagmatosporae and $O$. cucullatum to be Pesotum species, and they (Okada et al 2000) formally transferred G. erubescens to Pesotum. However, the phialidic conidiogenous cells, the loose aggregation of Leptographium-like conidiophores, and the absence of a Sporothrix anamorph lead us to believe that these species are distinct from Pesotum as originally conceived by Crane and Schoknecht (1973). Further, O. cucullatum and $O$. sagmatosporae, like most other Ophiostoma species with Leptographium or Phialographium anamorphs, have ascospores with thickened outer walls (sheaths) that are cucullate, to rectangular, to triangular, depending on the view (Solheim 1986). In contrast, ascospores in the $O$. piceae complex are allantoid to orange section shaped, and are relatively thinwalled, with no visible sheath.

Graphium species excluded from Ophiostoma.-There are numerous Graphium-like species that are related to ascomycetes other than Ophiostoma (Okada et al 1998), and it is beyond the scope of the present paper to discuss these in detail. However, we did examine material of five Graphium species from Hedgcock's specimens in BPI and other CBS cultures, and these examinations suggest that they are not closely related to Ophiostoma species.

Graphium album (Corda) Sacc., Syll. Fung. 4: 618. 1886. emended Hedgcock, Mo. Bot. Gard. Rept. 17: 96.1906.

三Ceratopodium album Corda, Ic. Fung. 1: 20. 1837.

Commentary. No type material of Corda's specimen is available (Seifert, pers comm), and his illustrations give little indication of the affinities of this species. It was found on Betula in Bohemia and described by Saccardo (1886) as having conidial masses that were white. Hedgcock (1906) emended the species description to include conidial masses white to creamyyellow, or light brown when old and dry, and our examination his specimen (BPI 448665, from Fagus in Arkansas, USA) showed the conidial masses to be yellow-gold. The yellow-gold to light-brown conidial masses of the BPI specimen suggests that G. album as emended by Hedgcock is not an Ophiostoma species. However, Hedgcock's fungus may not be G. album, and the disposition of Corda's species remains in question.

A culture from Pinus in CBS (276.54, deposited by Kåårik) is listed as G. album, but the culture does not match the BPI specimen or Hedgcock's emended description of G. album. Rather, Kåårik's culture is conspecific with her Graphium erubescens (MathiesenKåårik 1953). As discussed earlier, CBS 276.54 has the ITS sequence of $O$. cucullatum (anamorph $=$ Phial ographium erubescens). As Kåårik's culture is from 

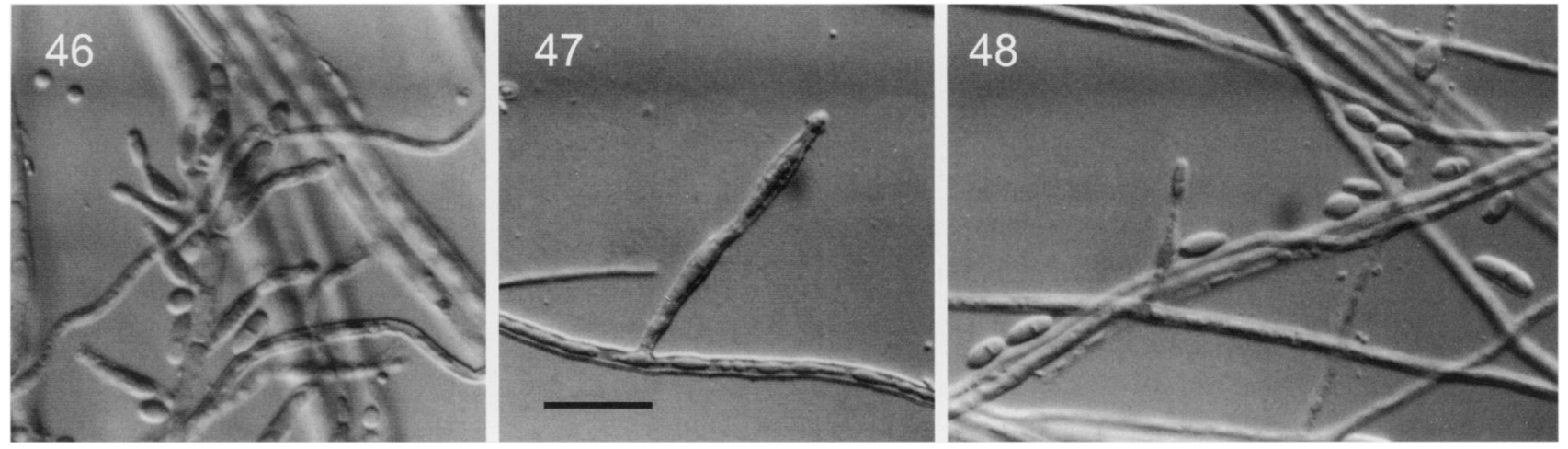

FIGS. 46-48. Graphium rubrum conidiophores and conidia. 46, 47 from strain C1223, AUTHENTIC FOR TYPE of G. rubrum; 48 from strain C1221, AUTHENTIC FOR TYPE of G. silanum. Scale bars $=10 \mu \mathrm{m}$.

pine, it seems unlikely that it is G. album as described by Corda.

Graphium ambrosiigerum Hedgcock, Mo. Bot. Gard. Rept. 17: 85. 1906.

Commentary. The holotype specimen (BPI 448676) and co-type (BPI 448675) are in poor condition, but both have synnemata with dark stipes and black conidial masses. The species was described from galleries of ambrosia beetles in Pinus arizonica in Arizona, USA. It is possible that Hedgcock was working with a mixture of an Ambrosiella species with a Graphium species. The black conidial masses on the synnema of the G. ambrosiigerum specimens are not typical for anamorphs of Ophiostoma species.

Graphium rigidum (Pers.) Sacc., Syll. Fung. 4: 610. 1886. emended Hedgcock, Mo. Bot. Gard. Rep. 17: 92. 1906.

Commentary. Seifert (1985) suggested that the name $G$. rigidum had been frequently used for fungi with black synnemata, and he considered the species a nomen dubium. Siemaszko (1939) considered G. rigidum as a synonym of $G$. penicillioides, and G. rigidum may be a member of the $G$. penicillioides complex (Okada et al 1998). A specimen (BPI 448820) from Quercus rubra sapwood from Indiana, USA deposited by Hedgcock in BPI as the emended type of G. rigi$d u m$, may be of more than one fungus. The synnemata in the specimen have black stipes from the base up to the yellow-gold conidial masses.

Graphium rubrum Rumbold, Phytopathology 24: 300. 1934.

FIGS. $46-47$

Commentary. A specimen deposited by Rumbold (BPI 448830) can serve as the holotype of G. rubrum, and it shows black synnematous stipes with pinkishred to yellowish-red conidial masses, and a few syn- nemata have gray conidial masses. A culture from the holotype (CBS 210.34) is no longer producing synnemata but is producing phialide-like structures on short, simple, hyaline conidiophores (FIGS. 46-47). Okada et al (2000) also observed phialides in CBS 210.34 using scanning electron microscopy.

Rumbold (1934) reported G. rubrum from Quercus, Populus, Liquidambar and Pinus in the USA. Goidanich (1936) described G. silanum from Pinus in Italy, and a culture (CBS 206.37) deposited by him produces no synnemata but does produce phialidelike structures on short, simple, hyaline conidiophores (FIG. 48), similar to those of G. rubrum. Also, CBS 206.37 has an ITS sequence identical to that of Rumbold's isolate of G. rubrum. It is possible, however, that CBS 206.37 is not G. silanum, as Goidanich described $G$. silanum as having a micronematous state with prominent denticles and ramoconidia, and

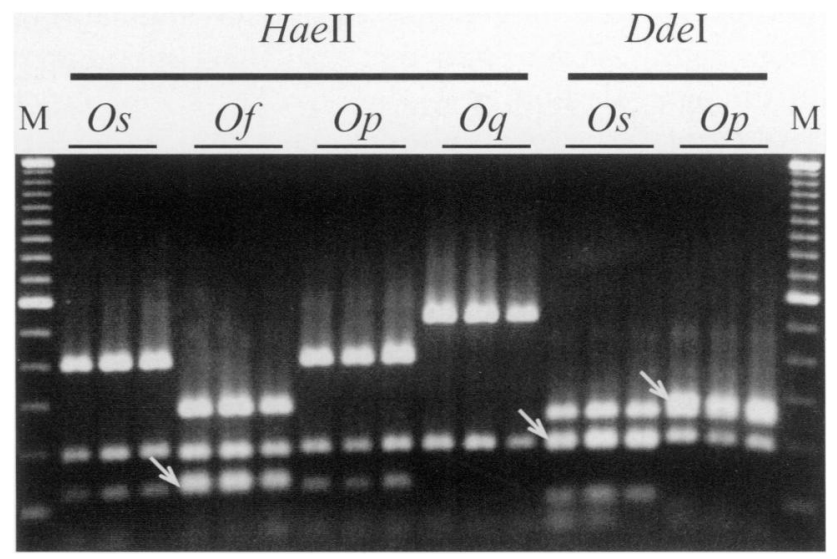

Fig. 49. Ethidium bromide stained agarose (2\%) gel of HaeII and Ddel digestion products of the amplified ITS rDNA region from isolates of Ophiostoma setosum (Os), Ophiostoma floccosum (Of), O. piceae $(O p)$, and $O$. querci $(O q)$. Co-migrating bands are indicated by arrows. Onehundred base pair ladders $(\mathrm{M})$ are on either side of the gel. 


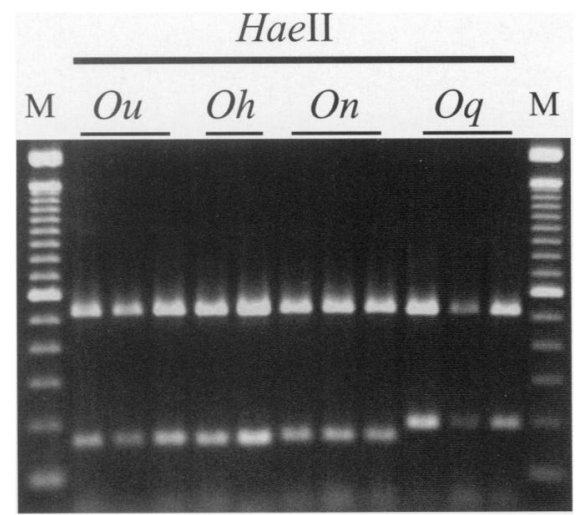

FIG. 50. Ethidium bromide stained agarose (2\%) gel of HaelI digestion products of the amplified ITS rDNA region from isolates of Ophiostoma ulmi $(\mathrm{Ou})$, O. himal-ulmi $(\mathrm{Oh})$, $O$. novo-ulmi $(O n)$, and $O$. querci $(O q)$. One-hundred base pair ladders $(\mathrm{M})$ are on either side of the gel.

CBS 206.37 does not form such a Sporothrix-like anamorph.

The ITS sequence (AF198245) of Rumbold's isolate CBS 210.34 did not match well with our sequences of Ophiostoma species. A BLAST 2.0 (NCBI) search showed this sequence to be closest to Phialophora gregata (Allington and Chamberlain) Gams, which may be an anamorph of an unknown discomycete (Paulin and Harrington 2000). The 18S rDNA sequence of Rumbold's culture also places it among the discomycetes (Okada et al 2000).

Dendrostilbella smaragdina (Alb. \& Schw.) Seifert, Stud. Mycol. 45: 185. 2000.

$\equiv$ Ceratopodium smaragdinum A. \& S., Consp. Fung., p. 335. 1805.

$\equiv$ Stilbum smaragdinum Alb. \& Schw.:Fr., Sytem. Mycol. 3: 303. 1832.

$\equiv$ Tubercularia smaragdinum (Alb. \& Schw.) Seifert, Stud. Mycol. 27: 127. 1985.

$\equiv$ Graphium smaragdinum (Alb. \& Schw.) Sacc., Syll. Fung. 4: 618. 1886.

Commentary. Seifert (1985) examined what was considered authentic material of this species and described the green synnemata and acropleurogenous phialides. Hedgcock (1906) noted green synnematous stipes and gray or green conidial masses, and we also found very dark conidial masses on his specimen (BPI 448617). Based on Seifert's description and Hedgcock's specimen, G. smaragdinum is not a likely member of the $O$. piceae complex. This species may have an unnamed Claussenomyces (discomycete) teleomorph (Okada et al 2000).

\section{DISCUSSION}

Although there have been earlier studies distinguishing the so-called conifer form of $O$. piceae from the so-called hardwood form, and the Dutch elm disease fungi have been clearly delimited from each other, this is the first comprehensive assessment of the entire complex. The ITS sequences of the nine recognized species were very similar to each other but quite distinct from the ITS sequences of $O$. ips, $O$. simplex, $O$. galeiformis, $O$. cucullatum, $O$. europhioides, $O$. pluriannulatum, $O$. coronatum, $O$. perfectum, $O$. nigrocarpum, $O$. stenoceras and other Ophiostoma species (data not shown). All members of the $O$. piceae complex form a Sporothrix synanamorph with prominent denticles in addition to the Pesotum synanamorph, and the presence of both synanamorphs sets the complex apart from the rest of Ophiostoma. Thus, this unique combination of anamorphs and the ITS sequence analysis suggest that $O$. piceae complex is a monophyletic group.

Graphium-like fungi outside the $\mathrm{O}$. piceae complex.Synnemata are efficient fruiting bodies for placing conidia in the path of small animals for acquisition and dispersal, and it is not surprising that many evolutionary lines of fungi have converged on such conidiomata. In a recent review of ascomycete-forming fungi with Graphium-like synnemata, Okada et al (1998) found that such synnemata are formed by species of the Microascales (pyrenomycetes) and Chaetothyriales (loculoascomycetes), and they recommend that the genus name Graphium be used only for the species with microascalean affinities, such as G. penicillioides. Further, we found that the ITS sequence of G. rubrum is closer to Phialophora gregata and discomycetes than to pyrenomycetes or loculoascomycetes, and G. rubrum produces a phialidic micronematous state, as does the synnematous Dendrostillbella smaragdina, which also appears to be a discomycete anamorph (Okada et al 2000). Species in Ophiostoma tolerate cycloheximide at high concentrations (Harrington 1981), and this can aid in separating synnema-forming species with Ophiostoma affinities from those of other ascomycetes. However, there are other ascomycetes, including some true Graphium species, like $G$. penicillioides, that are not related to Ophiostoma but do tolerate cycloheximide.

Even within Ophiostoma, synnemata may have evolved more than once. Ophiostoma is a large genus with a wide variety of anamorphs, and many species have more than one synanamorph. In addition to the Leptographium-type (mononematous, with a stipe and a penicillately branched conidiogenous apparatus) and the Graphium-type (synnematous), some species of Ophiostoma, such as the anamorph of $O$. clavigerum, show both types of conidiomata. Graphiocladiella was proposed by Upadhyay (1981) to accommodate anamorphic fungi with both mononematous and syn- 
nematous conidiomata. Harrington (1988) suggested that such intermediate types could be better accommodated in Graphium (Pesotum) than in Leptographium, but we now suspect that many such species have greater affinity with Leptographium.

Variability in conidiogenesis and stipe configuration among the anamorphs of Ophiostoma has led to a multitude of anamorph genera and continued controversy (Harrington 1988, Seifert and Okada 1993, Wingfield et al 1991). In some Ophiostoma species (TABLE III), the synnemata appear to be a loose aggregation of Leptographium conidiophores, without fused stipe cells. In our examination of Ophiostoma species, only members of the $O$. piceae complex have proven to produce both synnemata with fused stipe cells and a Sporothrix synanamorph (micronematous conidiophores with prominent denticles, Hoog 1974, 1993). Micronematous conidiophores are seen in many of the species listed in TABLE III, but these micronematous conidiophores lack prominent denticles at the conidiogenous cell apex and appear to be nearer to Hyalorhinocladiella (Hoog 1993) or to be degenerative Leptographium-type conidiophores. The conidiogenous cells of Pesotum and Leptographium resemble those of Hyalorhinocladiella, and it is possible that the macronematous conidiomata evolved from the Hyalorhinocladiella-like conidiophores.

Some of the synnemata-forming Ophiostoma species with ITS sequences differing greatly from those of $O$. piceae include $O$. ips, $O$. simplex, $O$. galeiformis and $O$. cucullatum. These species lack a Sporothrix anamorph, though $\mathrm{O}$. ips forms micronematous, $\mathrm{Hy}$ alorhinocladiella-like conidiophores (Hoog 1993). Many of these and other synnemata-forming Ophiostoma species without Sporothrix synanamorphs form ascospores with sheath-like outer walls, extending to a cucullate brim around the spores (e.g., O. clavigerum, O. simplex, O. galeiformis and $O$. cucullatum) or in a box shape (O. ips and $O$. ainoae). In contrast, reniform ascospores without thickened outer cell walls are typical for species in the O. piceae complex.

The genus Pesotum was defined by the presence of both synnemata and micronematous conidiophores with denticles, with the synanamorphs of Ophiostoma $u l m i$ as the type species (Crane and Schoknecht 1973). Accepting their definition, we would restrict Pesotum to those anamorphs with affinities to the $O$. piceae complex. Other synnematous anamorphs in Ophiostoma may have arisen through convergent evolution, perhaps from Leptographium-type conidiophores. The genus Phialographium is available for synnematous anamorphs of Ophiostoma species (e.g., $O$. sagmatosporae and $O$. cucullatum) with phialidic conidiogenous cells.
Species delimitation and identification in the $\mathrm{O}$. piceae complex.-Use of a wide array of isolates from around the world and a holistic approach, including mating reactions, phylogenetic analysis, and phenotype (morphological and physiological), allows for a clearer delimitation of the species in the $O$. piceae complex. We emphasize phenotype in delimiting species (Harrington and Rizzo 1999), but mating compatibilies and phylogenetic analyses prove valuable in identifying lineages or mating populations where unique phenotypic characters may be found. It is noteworthy that ITS sequences were unable to distinguish $O$. piceae from $O$. canum, two species that are morphologically and biologically distinct. Other studies (Harrington and Rizzo 1999, Witthuhn et al 2000) have also found that ITS sequences of sympatric sibling species may be identical, and a strictly genealogical species concept cannot be applied if only nuclear rDNA sequences are utilized.

Production of the sexual state in culture is relatively easy for species in the $O$. piceae complex, and the heterothallic nature of most of the species allows for the identification of mating populations or biological species. Partial interfertility between species, as evidenced by poor ascospore production or aborted asci (Brasier 1993, Harrington and McNew 1998) was seen in some pairings between different species, and this strongly suggests that the species are distinct. In pairings between isolates of the same species, we generally had more success in producing perithecia and ascospores by spermatizing a recipient (female) strain with conidial suspensions of a donor (male) strain than by simply pairing two strains together on a agar medium. Two mating types are seen in $O$. ulmi, O. novo-ulmi, O. himal-ulmi (Brasier and Mehrotra 1995), O. piceae, O. querci, (Brasier 1993), O. setosum (Uzunovic et al 2000), and O. floccosum, but Goidanich (1935) reported O. catonianum to be homothallic.

A number of physiological and morphological characters were found useful in identifying cultures to species (TABLE II). Many of these characters have been used by others (Brasier and Kirk 1989, 1993, Brasier and Stephens 1991, 1993, Hamschlager et al 1994, Pipe et al 1995, Webber and Brasier 1990) to distinguish $O$. piceae and $O$. querci. Some overlapping morphological characters have been used to distinguish these two species, and these characters, growth at $32 \mathrm{C}$, and mating reactions with testers are sufficient to identify species in the complex, but a more rapid and objective identification criterion is the RFLP patterns of the amplified ITS region.

We did not attempt to distinguish $O$. ulmi, O. novo$u l m i$, and $O$. himal-ulmi by the PCR-RFLP technique, although ITS sequence divergence should allow de- 
velopment of a similar protocol for distinguishing these three species. More importantly, the species most commonly found on conifer sapwood $(O . p i$ ceae, $O$. floccosum, $O$. querci and $O$. setosum) can be identified by ITS-RFLP patterns. With experience, it is possible to amplify the ITS region using scrapes of mycelium for template DNA. Kim et al (1999) showed that the ITS region of species in the $O$. piceae complex can also be amplified directly from conidia at the apex of synnemata, and primers were designed to distinguish $O$. piceae and $O$. querci. With the RFLP diagnostic technique employed here, more species can be distinguished. Without the need for DNA extraction, the PCR-RFLP technique can be completed in a single day, as has been demonstrated for members of Armillaria (Harrington and Wingfield 1995).

Phylogenetic analysis of the ITS region supports the distinction between $O$. piceae and $O$. querci, with $O$. piceae grouping with other species (O. canum, $O$. floccosum, and $O$. setosum) found primarily on conifers. In contrast, $O$. querci has been reported primarily from hardwoods in Europe, as have its relatives, $O$. catonianum and the Dutch elm disease fungi. However, O. querci is apparently common on sapwood of Pinus and other Pinaceae in North America and the Southern Hemisphere.

Conifer-inhabiting species of the $\mathrm{O}$. piceae complex.Ophiostoma canum, $O$. floccosum, and $O$. setosum have only been isolated from conifers and are more closely related to $O$. piceae than to the species found primarily on hardwoods. The ITS sequence of $O$. canum is not distinguishable from that of $O$. piceae, but lack of interfertility with $O$. piceae mating testers and the distinctive conidia of $O$. canum set this species apart. Partial interfertility with $O$. piceae suggests that both of our isolates of $O$. canum are mating type B; thus, we do not appear to have the opposite mating type for production of perithecia and ascospores in culture. The other conifer-inhabiting species appear to be common sapwood staining fungi not associated with any particular insect vector, but $O$. canum may be an important symbiont with a specific insect (the bark beetle Tomicus minor, Mathiesen 1950). The collection of thick-walled conidia at the apex of the synnemata may be an adaptation for mycophagy by the bark beetle.

Our primary interest in the $O$. piceae complex has been in those species that cause bluestain in conifer wood. The most common synnemata-forming species we have encountered in New Zealand and western North America are O. piceae, O. floccosum, O. setosum, and $O$. querci. It is relatively common to see two or more of these species on a single chip of wood, and mixed cultures of these species are very fre- quently seen, so these species apparently grow together well, with little inhibition of each other. Such mixed cultures have likely contributed to the confusion over the identification of these species. Unfortunately, the work done on $O$. piceae as a bluestain fungus (as reviewed by Seifert 1993) is difficult to interpret now that we realize that the studies could have utilized $O$. querci, $O$. floccosum or $O$. setosum.

Hardwood-inhabiting species of the $\mathrm{O}$. piceae complex.-The taxonomy of $O$. querci remains unclear, and the basionym for the species is not ideal. No Latin description, dried specimen or culture was provided by Georgévitch $(1926,1927)$, but the fact that he described the fungus from oak in Europe (Croatia) makes it likely that his concept of the species matches the modern concept of the "hardwood form" of O. piceae. Accepting this, Loos' (1932) species, $O$. fagi, is a clear synonym. We do not have authentic material for $O$. roboris, $O$. kubanicum, and $O$. valachicum, but these, too, are likely synonyms of $O$. querci. If $O$. roboris is a synonym, then Graphium roboris would be the earliest available name for the synnematous anamorph of $O$. querci. Okada et al (1998) proposed Pesotum pirinum as the anamorph of $O$. querci, but this is the anamorph name for Ophiostoma catonianum, which we consider distinct from $O$. quer$c i$. We also examined isolates from New Zealand and Vietnam that looked similar to $O$. querci but differed slightly in ITS sequence, and these cultures did not mate with $O$. querci testers. We suspect that more species closely related to $O$. querci will be recognized in the future.

The relatedness of $O$. querci to the Dutch elm disease fungi $O$. ulmi and $O$. novo-ulmi was demonstrated by similarity of ITS sequences. These Dutch elm disease fungi are very closely related but distinct species that have been introduced to North America and Europe. They may be native to Asia, though they have not been found there (Brasier 1990, Brasier and Mehrotra 1995). Ophiostoma himal-ulmi does appear to be native to the Himalayas, where it was found associated with bark beetle attacks in elm branches (Brasier and Mehrotra 1995). In inoculation studies, O. himal-ulmi was able to cause a vascular wilt disease in elm seedlings, and it was thought that this species was closely related to $O$. ulmi and $O$. novo-ulmi (Brasier and Mehrotra 1995). However, the ITS sequence analysis suggests that $O$. himal-ulmi is more closely related to $O$. querci.

The capacity of $O$. querci to cause disease in hardwood species has been debated, and fungi similar to $O$. querci have been frequently associated with declining oak trees in Europe (Brasier 1990, Brasier and Kirk 1989, Brasier and Mehrotra 1995, Harrington 
1993, Morelet 1992, Oleksyn and Przybyl 1987). Its close relationship to $O$. himal-ulmi, $O$. ulmi, and $O$. novo-ulmi also suggests that it has the potential to cause a vascular disease, and attention should be given to introduction of this species to new environments.

We suspect that most species in the $O$. piceae complex are native to the Northern Hemisphere. Indeed, the common occurrence of $O$. querci on sapwood of Pinaceae in some regions (such as the Southern Hemisphere and North America) may be due to its not being native to these ecosystems. This species and others in the complex will produce synnemata and/ or perithecia on logs, crating, dunnage and other materials commonly discarded from ships, and we believe that the wide distribution of some of these species is due to human activities.

\section{ACKNOWLEDGMENTS}

We acknowledge various herbaria, culture collections and colleagues for providing us with specimens and cultures for study. Such contributions by R. Blanchette of the University of Minnesota, Stuart Kay of the Hort Research Institute of New Zealand, H. Solheim of the Norwegian Forest Research Institute, J. Webber and C. Brasier of the UK Forestry Commission, and M. J. Wingfield of the University of Pretoria are especially acknowledged. The technical assistance of J. Blake is also noted. Lynn Clark, Iowa State University, kindly provided the Latin description. Keith Seifert made many helpful suggestions on the manuscript. Journal Paper No. J-18741 of the Iowa Agriculture and Home Economics Experiment Station, Ames, Iowa, Project No. 3226, and supported by Hatch Act and State of Iowa funds.

\section{LITERATURE CITED}

Bakshi BK. 1951. Studies on four species of Ceratocystis, with a discussion on fungi causing sapstain in Britain. Commonw Mycol Inst Mycol Pap No 35:1-16.

$\rightarrow$ Blackwell M. 1994. Minute mycological mysteries: the influence of arthropods on the lives of fungi. Mycology 86: $1-17$.

Brasier, CM. 1990. China and the origins of Dutch elm disease: an appraisal. Plant Pathol 39:5-16.

- 1993. The genetic system as a fungal taxonomic tool: gene flow, molecular variation and sibling species in the 'Ophiostoma piceae Ophiostoma ulmi' complex and its taxonomic and ecological significance. In: Wingfield MJ, Seifert KA, Webber JF, eds. Ceratocystis and Ophiostoma: taxonomy, ecology and pathogenicity. St. Paul, Minnesota: American Phytopathological Society Press. p 78-95.

- Kirk SA. 1989. European oak decline, identity of Ophiostoma roboris. In: Report on forest research. London: HMSO. p 47-48. $\longrightarrow$ ceae. Mycol Res 97:811-816.
—, Mehrotra MD. 1995. Ophiostoma himal-ulmi sp. nov., a new species of Dutch elm disease fungus endemic to the Himalayas. Mycol Res 99:205-215.

— Stephens TM. 1991. Diagnostic test to distinguish species in 'Ophiostoma piceae'. In: Report on Forest Research, London: HMSO. p 38-39.

- - 1993. Temperature-growth responses distinguish the OPC and OPH sibling species within 'Ophiostoma piceae'. Mycol Res 97:1416-1418.

Butin H. 1968. A new species of Ceratocystis causing bluestain in Araucaria araucana. Can J Bot 46:61-63.

Crane JL, Schoknecht JD. 1973. Conidiogenesis in Ceratocystis ulmi, Ceratocystis piceae and Graphium penicillioides. Am J Bot 60:346-354.

Dalpé Y, Montant C. 1980. L'effet d'acides gras saturés et insaturés sur la croissance et la fructification de quelques espèces du genre Ceratocystis. Can J Bot 58: 2543-2548.

Davidson RW. 1935. Fungi causing stain in logs and lumber in the southern states, including five new species. J Agric Res 50:789-807.

- 1955. Wood-staining fungi associated with bark beetles in Engelmann spruce in Colorado. Mycologia 47: 58-67.

- 1958. Additional species of Ophiostomataceae from Colorado. Mycologia 50:661-670.

- 1971. New species of Ceratocystis. Mycologia 63:515.

DeScenzo RA, Harrington TC. 1994. Use of $(\mathrm{CAT})_{5}$ as a DNA fingerprinting probe for fungi. Phytopathology 84:534-540.

Felsenstein J. 1985. Confidence limits on phylogenies: an approach using the bootstrap. Evolution 39:783-791.

Gardes M, Bruns TD. 1993. ITS primers with enhanced specificity for basidiomycetes-application to the identification of mycorrhizae and rusts. Mol Ecol 2:113118.

Georgévitch P. 1926. Ceratostomella querci n. sp. Compt Rend Heb Seances Acad Sci, Paris 183:759-761.

- 1927. Ceratostomella quercus $n$. sp. Ein parasit der slawonischen eichen. Biol Gen 3:245-252.

Goidanich G. 1935. Una nuova specie di "Ophiostoma" vivent sul pero ed alcune ossevazioni sull'esatta posizione sistematica della forma ascofora e delle forme metagenetiche del genere. Boll Staz Patol Veg Roma, N Ser 15:122-168.

_ 1936. Le alterazioni cromatiche parassitarie del legname in Italia. Boll Staz Patol Veg Roma, N Ser 16:225270.

Griffin HD. 1966. The genus Ceratocystis in Ontario. Can J Bot 46:689-718.

Halmschlager E, Messner R, Kowalski T, Prillinger H. 1994. Differentiation of Ophiostoma piceae and Ophiostoma quercus by morphology and RAPD analysis. Syst Appl Microbiol 17:554-562.

Harrington TC. 1981. Cycloheximide sensitivity as a taxonomic character in Ceratocystis. Mycologia 73:11231129.

- 1987. New combinations in Ophiostoma of Cerato- 
cystis species with Leptographium anamorphs. Mycotaxon 28:39-43.

- 1988. Leptographium species, their distribution, hosts, and insect vectors. In: Harrington TC, Cobb FW $\mathrm{Jr}$, eds. Leptographium root diseases on conifers. St. Paul, Minnesota: American Phytopathological Society Press. p 1-39.

- 1992. Leptographium. In: Singleton LL, Mihail JD, Rush CM, eds. Methods for research on soilborne phytopathogenic fungi. St. Paul, Minnesota: American Phytopathological Society Press. p 129-133.

- 1993. Diseases of conifers caused by species of Ophiostoma and Leptographium. In: Wingfield MJ, Seifert KA, Webber JF, eds. Ceratocystis and Ophiostoma: taxonomy, ecology and pathogenicity. St. Paul, Minnesota: American Phytopathological Society Press. p 161172.

- McNew DL. 1997. Self-fertility and uni-directional mating type switching in Ceratocystis coerulescens, a filamentous ascomycete. Curr Genet 32:52-59.

— -1998 . Partial interfertility among the Ceratocystis species on conifers. Fung Genet Biol 25:44-53.

- Rizzo DM. 1999. Defining species in the fungi. In: Worrall JJ, ed. Structure and dynamics of fungal populations. Dordrecht, The Netherlands: Kluwer Academic Publishers. p 43-71.

—, Wingfield BD. 1995. A PCR-based identification method for species of Armillaria. Mycologia 87:280288.

Hausner G, Reid J, Klassen GR. 1993. On the phylogeny of Ophiostoma, Ceratocystis s.s., and Microascus, and relationships within Ophiostoma based on partial ribosomal DNA sequences. Can J Bot 71:1249-1265.

Hedgcock GG. 1906. Studies upon some chromogenic fungi which discolor wood. Missouri Bot Gard Rep 17:59114.

Hoog GS de. 1974. The genera Blastobotrys, Sporothrix, Calcarisporium and Calcarisporiella gen. nov. Stud Mycol 7: $1-84$.

- 1993. Sporothrix-like anamorphs of Ophiostoma species and other fungi. In: Wingfield MJ, Seifert KA, Webber JF, eds. Ceratocystis and Ophiostoma: taxonomy, ecology and pathogenicity. St. Paul, Minnesota: American Phytopathological Society Press. p 53-60.

- Scheffer RJ. 1984. Ceratocystis versus Ophiostoma: a reappraisal. Mycologia 76:292-299.

Hunt J. 1956. Taxonomy of the genus Ceratocystis. Lloydia 19:1-58.

Hutchison LJ, Reid J. 1988a. Taxonomy of some potential wood-staining fungi from New Zealand. 1. Ophiostomataceae. New Zealand J Bot 26:63-81.

$-1988 \mathrm{~b}$. Taxonomy of some potential woodstaining fungi from New Zealand. 2. Pyrenomycetes, Coelomycetes and Hyphomycetes. New Zealand J Bot 26:83-98.

Jacobs K, Wingfield MJ, Bergdahl DR. 1997. A new Ophiostoma species with a Graphium anamorph from Larix laricina in eastern North America. Mycologia 89:332338.

Kim SH, Uzunovic A, Brueil C. 1999. Rapid detection of
Ophiostoma piceae and $O$. quercus in stained wood by PCR. Appl Environ Microbiol 65:287-290.

Loos W. 1932. Uber eine buchenholzbewohnende Ceratostomella, Ceratostomella fagi nov. sp. Arch Microbiol 3: 370-383.

Mathiesen A. 1950. Uber einige mit borkenkafern assoziierte blauepilze in Schweden. Oikos 2:275-308.

1951. Einige neue Ophiostoma-arten in Schweden. Svensk Bot Tidsk 45:203-232.

Mathiesen-Käärik A. 1953. Eine Ubersicht uber die gewohnlichsten mit Borkenkafern assoziierten Blauepilze in Schweden und einige fur Schweden neue Blauepilze. Meddeland Statens Skogs-Forskningsinst 43:1-74.

. 1960. Studies on the ecology, taxonomy and physiology of Swedish insect-associated blue stain fungi especially the genus Ceratocystis. Oikos 11:1-25.

Morelet M. 1992. Ophiostoma querci sur chêne en France. Ann Soc Sci Nat Archeol Toulon Var 44:109-112.

Münch E. 1907. Die bläufaule des nadelholzes. I-II. Naturwiss Z Forst-Landw 5:531-573.

Olchowecki A, Reid J. 1974. Taxonomy of the genus Ceratocystis in Manitoba. Can J Bot 52:1675-1711.

Okada G, Jacobs K, Kirisits T, Louis-Seize GW, Seifert KA, Sugita T, Takematsu A, Wingfeild MJ. 2000. Epitypification of Graphium penicillioides Corda, with comments on the phylogeny and taxonomy of graphium-like synnematous fungi. Stud Myc 45:169-188.

- Seifert KA, Takematsu A, Yamaoka Y, Miyazaki S, Tubaki K. 1998. A molecular phylogenetic reappraisal of the Graphium complex based on $18 \mathrm{~S}$ rDNA sequences. Can J Bot 76:1495-1506.

Oleksyn J, Przybyl K. 1987. Oak decline in the Soviet Union-scale and hypotheses. Eur J For Pathol 17:321336.

Paulin A, Harrington T. 2000. Phylogenetic placement of anamorphic species of Chalara among Ceratocystis species and other ascomycetes. Stud Mycol 45:209-222.

Pipe ND, Buck KW, Brasier CM. 1995. Genomic fingerprinting supports the separation of Ophiostoma piceae into two species. Mycol Res 99:1182-1186.

Potlajezuk VI, Schekunova EG. 1985. De distributione specierum generis Ceratocystis Ell. et Halst. emend. Bakshi in URSS. Nov Sistematiki Mizshikh Rastenii 22:148156.

Przybyl K, Hoog GS, de. 1989. On the variability of Ophiostoma piceae. Anton Leeuw 55:177-188.

Robinson-Jeffrey RC, Davidson RW. 1968. Three new Europhium species with Verticicladiella imperfect states on blue-stained pine. Can J Bot 46:1523-1527.

Rumbold CT. 1931. Two blue-staining fungi associated with bark-beetle infestation of pines. J Agric Res 43:847-873.

- 1934. A new species of Graphium causing lumber stain. Phytopathology 24:300-301.

Saccardo PA. 1886. Sylloge Fungorum. Vol. IV. 807 p.

Seifert KA. 1985. A monograph of Stilbella and some allied hyphomycetes. Stud Mycol 27:1-235.

- 1993. Sapstain of commercial lumber by species of Ophiostoma and Ceratocystis. In: Wingfield MJ, Seifert KA, Webber JF, eds. Ceratocystis and Ophiostoma: tax- 
onomy, ecology and pathogenicity. St. Paul, Minnesota: American Phytopathological Society Press. p 141-151.

, Okada G. 1993. Graphium anamorphs of Ophiosto$m a$ species and similar anamorphs of other ascomycetes. In: Wingfield MJ, Seifert KA, Webber JF, eds. Ceratocystis and Ophiostoma: taxonomy, ecology and pathogenicity. St. Paul, Minnesota: American Phytopathological Society Press. p 27-41.

Siemaszko W. 1939. Zespoly grzybow towarzyszacych kornikom polskim. Planta Pol 7:1-52.

Solheim H. 1986. Species of Ophiostomataceae isolated from Picea abies infested by the bark beetle Ips typographus. Nord J Bot 6:199-207.

Spatafora JW, Blackwell M. 1994. The polyphyletic origins of Ophiostomatoid fungi. Mycol Res 98:1-9.

Swofford DL. 1998. PAUP*: phylogenetic analysis using parsimony (*and Other Methods). Version 4. Sunderland, Massachusetts: Sinauer Associates.

Upadhyay HP. 1981. A monograph of Ceratocystis and Ceratocystiopsis. Athens, Georgia: The University of Georgia Press. 176 p.

, Kendrick WB. 1975. Prodromus for a revision of Ceratocystis (Microascales, Ascomycetes) and its conidial states. Mycologia 67:798-805.

Uzunovic A, Seifert KA, Kim SH, Breuil C. 2000. Ophiostoma setosum, a common sapwood staining fungus from western North America, a new species of the Ophiostoma piceae complex. Mycol Res 104:486-494.

Webber JF, Brasier CM. 1990. Status of Ophiostoma piceae on hardwoods and conifers. In: Report on forest research. London: HMSO. p 54-55.

White TJ, Bruns T, Lee S, Taylor J. 1990. Amplification and direct sequencing of fungal ribosomal RNA genes for phylogenetics. In: Innis MA, Gelfand DH, Sninsky JJ, White TJ, eds. PCR protocols: a guide to methods and application. San Diego: Academic Press. p. 315-322.

Wingfield MJ, Kendrick B, Schalk van Wyk P. 1991. Analysis of conidium ontogeny in anamorphs of Ophiostoma: Pesotum and Phialographium are synonyms of Graphium. Mycol Res 95:1328-1333.

Witthuhn RC, Harrington TC, Steimel JP, Wingfield BD, Wingfield MJ. 2000. Comparison of isozymes, rDNA spacer regions, and MAT-2 DNA sequences as phylogenetic characters in the analysis of the Ceratocystis coerulescens complex. Mycologia 92:447-452.

Wright EK, Cain RF. 1961. New species of the genus Ceratocystis. Can J Bot 39:1215-1230.

Yamaoka Y, Wingfield MJ, Takahashi I, Solheim H. 1997. Ophiostomatoid fungi associated with the spruce bark beetle Ips typographus f. japonicus in Japan. Mycol Res 101:1215-1227. 